\title{
THE MINERALOGY OF THE BELLEROPHON-NELSON TELLURIDE-BEARING GOLD DEPOSIT, ST. IVES CAMP, YILGARN CRATON, WESTERN AUSTRALIA
}

\author{
YUNXING XUE ${ }^{\S}$ AND IAN CAMPBELL \\ Research School of Earth Sciences, Australian National University, Canberra, ACT 0200, Australia
}

\begin{abstract}
The newly discovered Bellerophon-Nelson telluride-bearing gold deposit at the St. Ives camp, Western Australia, is hosted by meta-sedimentary rocks of the lower Black Flag Group and alkaline intrusions. Four stages of mineralization are recognized; from oldest to youngest these are: quartz-carbonate veins (Stage I), quartz-albite-carbonate-pyrite veins and sericitepyrite seams (Stage II), quartz-pyrite veins (Stage III), and carbonate \pm chlorite veins (Stage IV). Stages II and III contain economic gold mineralization, and the gold grains are strongly associated with pyrite. Intense albite and hematite alteration surround the mineralized veins, and trace amounts of gold precipitated in these altered rocks. The albite and hematite alterations are synchronous and derived from the same oxidized fluid as the auriferous veins. The occurrence and absence of hematite within the alteration zone reflects variable amounts of magnetite in the precursor rocks. Thirteen species of telluride and sulfosalt minerals have been identified in Stages II and III. The most common telluride minerals include calaverite, petzite, tellurobismuthite, and altaite, and these minerals have similar occurrences to native gold. In addition to native gold, telluride and sulfosalt minerals are also major $\mathrm{Au}$ carriers and account for at least $15 \%$ of the gold in this deposit. The mineral associations of $\mathrm{PbCl}(\mathrm{OH})-\mathrm{Pb}_{2} \mathrm{Cl}_{3}(\mathrm{OH})-\mathrm{Te}-\mathrm{TeO}_{2}$ and $\mathrm{BiOCl}-\mathrm{BiO}(\mathrm{OH}, \mathrm{Cl})-\mathrm{Te}-\mathrm{TeO}_{2}$ were formed as replacement of earlier telluride minerals as the result of reactions with $\mathrm{Cl}$-bearing fluids. The intergrowth between native gold and $\mathrm{Cl}$-bearing minerals + native Te/Te-oxide indicates that $\mathrm{Au}$ in telluride minerals was remobilized and re-deposited. The phase diagram for the telluride and sulfosalt mineral association suggests that during Stage II $\log f \mathrm{~S}_{2}$ decreased from -8 to -11 , and that $\log \mathrm{TTe}_{2}$ increased from -8 to the level required for the formation of Te-oxide. The values of $\log f \mathrm{Te}_{2}$ and $\log f \mathrm{~S}_{2}$ in the Stage III veins were -8 to -11 and -9 to -11.5 , respectively. The highly oxidized, tellurium-enriched hydrothermal fluid, which formed the Bellerophon gold telluride deposit, is consistent with the involvement of magmatic fluid, and sulfidation is the likely cause of gold precipitation.
\end{abstract}

Keywords: Bellerophon-Nelson gold deposit, St Ives, Yilgarn craton, telluride minerals, Archaean

\section{INTRODUCTION}

Archaean greenstone terranes host numerous gold deposits, e.g., the Yilgarn craton in Western Australia and the Superior craton in Canada, with $>9200$ tons and $>8500$ tons gold resources respectively (Robert et al. 2005). The most widely accepted hypothesis for the origin of the Achaean greenstone gold deposits in the Yilgarn craton is the orogenic gold model of Groves et al. (1998). However, this hypothesis cannot explain the well-known spatial associations between Archaean gold deposits and felsic alkaline intrusions (Witt 1992, Robert 2001). Two endmember hypotheses exist to explain the gold-intrusion link: (1) the auriferous fluid was derived from a magmatic intrusion (Robert 2001, Mueller et al. 2008, Stoltze 2006, Qui \& McNaughton 1999, Walshe et al. 2008) and (2) the competency contrast between the intrusion and wall rocks produced a structural trap for younger mineralization (Duuring et al. 2000, Brown et al. 2002, Witt 1992). Because of the identical ages and $\mathrm{Sr} / \mathrm{Nd}$ isotope compositions between the gold mineralization and the alkaline intrusions, the Granny Smith-Wallaby gold deposits have been interpreted as having a magmatic origin (Mueller et al. 2008, Stoltze 2006). In contrast, an age difference between the gold mineralization and adjacent intrusions has been reported for the Kanowna Belle gold deposit (Ross et al. 2004). The gold mineralization at the Golden Mile deposit in Western Australia has a different age from the mineralized dolerite, but identical dating results with the lamprophyre dikes (Heath 2003, Rasmussen et al. 2009, McNaughton et al. 2005). Various approaches have been applied to study this question, but no consensus has been reached, e.g., fluid inclusions (Ho et al. 1992), U-Pb dating (Duuring et al. 2004, Mueller et al.

\footnotetext{
$\S$ Corresponding author e-mail address: porphyry.yxxue@gmail.com
} 
2008), Nb-Sr isotopes (Stoltze 2006), multiple-S isotopes (Xue et al. 2013).

Gold has been mined from the St. Ives gold camp in the Eastern Goldfields Superterrane (EGST) of the Yilgarn Craton, Western Australia for over 100 years, and it has become the second largest gold producer in Australia (pers. commun. with Julian Woodcock, St. Ives Exploration Manager). Multiple deposits have been mined, the most important being AthenaHamlet, Victory-Defiance, and Revenge. However, the Bellerophon-Nelson prospect (hereafter shortened to Bellerophon), about $60 \mathrm{~km}$ south-southeast of Kalgoorlie, is of particular interest. The host rocks are felsic meta-sedimentary rocks, in contrast to the other deposits of the St. Ives camp, which are hosted in basalt, komatiite, black shale, or dolerite. There is a close association with alkaline felsic intrusions, which are also mineralized (e.g., Granny Smith and Wallaby gold deposits, Mueller et al. 2008). This study describes the geology, alteration, and mineralogy of the Bellerophon prospect. Thirteen telluride and sulfosalt minerals have been found in this deposit, some of which, e.g., calaverite, petzite, buckhornite, are important $\mathrm{Au}$ carriers. These telluride and sulfosalt minerals will be described in detail, and the relationship between the gold mineralization and felsic intrusions will be discussed.

\section{Geological Setting}

The Yilgarn craton, formed between $>3.0 \mathrm{Ga}$ and $2.6 \mathrm{Ga}$, has been divided into six terranes (Cassidy et al. 2006): Narryer, South West, central Youanmi, Kalgoorlie, Kurnalpi, and Burtville. The latter three constitute the Eastern Goldfield Superterrane (EGST). Among these terranes, the EGST is the most productive gold producer and hosts 15 of the 19 known world-class gold deposits in the Yilgarn (Cassidy \& Hagemann 2001).

The greenstone rocks in the EGST are composed of the older Kambalda sequence (2720-2690 Ma, Swager 1997, Krapež et al. 2000), which is uncomformably overlain by the Kalgoorlie sequence $(2690-<2660$ Ma, Krapež et al. 2000, Squire et al. 2010). The Kambalda sequence consists of mafic-ultramafic volcanic rocks, locally over $5000 \mathrm{~m}$ thick, interbedded with minor black shale horizons. The Black Flag Group and the younger Merougil Group, which together form the Kalgoorlie sequence, consist of meta-sandstone and felsic volcaniclastic rocks, and in the case of the Merougil Group, thick layers of conglomerate. These sequences were intruded by numerous mafic and intermediate to felsic intrusions (Champion \& Sheraton 1997, Nelson 1997). The mafic dolerite intrusions, e.g., Condenser, Junction, and Defiance dolerites, have been dated at $2680 \pm 8 \mathrm{Ma}$ (Bateman et al. 2001), whereas the intermediate to felsic intrusions have ages of 2680 to $2600 \mathrm{Ma}$ (Nelson 1997, Krapež et al. 2000,
Compston et al. 1986, Nguyen 1997). Lamprophyre intrusions in the Kalgoorlie and Kambalda areas have been dated to around $2.63 \mathrm{Ga}$, which is coeval with the gold mineralization (McNaughton et al. 2005, Perring \& McNaughton 1992). The EGST is cut by crustal-scale NNW-trending faults. Blewett et al. (2010) recognized seven stages of deformation. Gold mineralization mainly occurred at the third extensional stage and the fourth and fifth stages, which involved shearing and thrusting (Czarnota et al. 2008, Blewett et al. 2010).

\section{Methodology}

Polished thin sections with a thickness of $30 \mu \mathrm{m}$ were made for those samples of interest at the Australian National University. Detailed microscope observations elucidated the mineral relations and mineralization processes. Compositions of minerals of interest, dominantly sulfide telluride and sulfosalt minerals (samples were coated with $\sim 20 \mathrm{~nm}$ of carbon), were determined using a JEOL 6400 SEM (Electron Microscopy Unit, now Center of Advanced Microscopy, ANU) with EDS operating at $15 \mathrm{kV}$ and a focused beam $(1 \mu \mathrm{m})$ of $1 \mathrm{nA}, 120 \mathrm{~s}$ counting time, and a $17-20 \mathrm{~mm}$ working distance. Due to the high resolution achieved, mixed analyses can be avoided, which is important for analyzing fine-grained mineral phases. Back-scattered images were also used to investigate the phase relations.

\section{Regional Metamorphism}

The metamorphic grade of host rocks to the Belleronphon gold prospect is upper greenschist. Common metamorphic minerals include quartz, carbonate, biotite, chlorite, sericite, and epidote. The metamorphic mineral assemblage reflects the mineralogy of the precursor rock; some samples are biotiterich, whereas others are rich in quartz and plagioclase. Chlorite may replace epidote and biotite in response to retrograde metamorphic reactions. Magnetite and/or rutile can be found intergrown with chlorite following the breakdown of biotite, and plagioclase has been altered to sericite and calcite. Metamorphic rocks close to mineralization show foliation defined by chlorite, biotite, and sericite. Small veinlets occur parallel to the foliation. The mineral assemblage in the veinlets is similar to the host metamorphic rocks, suggesting that the veinlets formed during or after the regional metamorphism. Opaque minerals in these veins include pyrite + magnetite + chalcopyrite + pyrrhotite. Magnetite close to the mineralization can be oxidized to hematite, but this reaction is not seen elsewhere. As documented in the following text, the mineralizationrelated hydrothermal alteration overprinted the metamorphic minerals; hence, the mineralization should be later than the regional metamorphism. The dating 
results of muscovite in the mineralized veins support this interpretation (Xue 2014). In regional geology, five phases of metamorphism have been recognized (Goscombe et al. 2007), with the dominant metamorphism in EGST being the combination of M2 and M3a. The M2 metamorphism is coeval with the emplacement of regional high-Ca granite and the East-West compression deformation. The M3a metamorphism is characterized by the extensional settings and regional rifting. It is worth noting that lamprophyre dikes younger than the regional metamorphism have been recognized in the Kalgoorlie and Kambalda areas (McNaughton et al. 2005, Perring \& McNaughton 1992, Rock et al. 1990).

\section{Deposit Geology}

The host rocks of the Bellerophon gold prospect are mainly sandstone and siltstone, interlayered with chert and volcaniclastic rocks (Fig. 1). Monzonite and albitite felsic bodies, which intrude the supracrustal rocks, are also mineralized (Fig. 1b) and can contain gold in concentrations $>20 \mathrm{ppm}$. The mineralization at Bellerophon has been divided into four stages, based on a combination of field relationships, microscopic textures, and SEM studies (Fig. 2), which from oldest to youngest are: Stage I, quartz-carbonate veins; Stage II, quartz-albite-carbonate-pyrite veins and sericite-pyrite seams; Stage III, quartz-pyrite veins; and Stage IV, carbonate \pm chlorite veins. Stage II and Stage III account for most of the native gold and telluride mineralization.

Three alteration zones have been observed at Bellerophon (Fig. 1b). Most distal is the chlorite alteration zone, which also contains small amount of sericite. The mineral assemblage in this zone is attributed to the combined effects of alteration by auriferous fluid and regional metamorphism. Sericite abundances in the intermediate zone increase with proximity to mineralization. This zone also contains variable amounts of hematite and albite in association with hydrothermal carbonate and quartz. There are two types of alteration in the proximal zone, intense hematite alteration and albite alteration (Fig. 3). Both can envelop the mineralized veins. In some cases, the two types of alteration combine to form albite+hematite alteration, which has been found in both the sandstone and volcaniclastic wall rocks (Fig. 3). Monzonite intrusions show intense albite alteration, whereas the albitite dike rocks are hematite altered (Fig. 3). Proximal albite and hematite altered rocks can carry native gold, and locally, the sericite alteration is also weakly mineralized (Fig. 1b).

\section{Stage I}

The principal minerals in the Stage I veins are quartz and carbonate (Fig. 4a), which are locally accompanied by rare apatite and pyrite. The veins are not common and mostly occur at the contact between dark green regional metamorphic rocks and pale to brick-red mineralized zones. The veins are generally only a few tens of centimeters in length, and trend sub-parallel to the regional foliation. Native gold has not been observed in Stage I veins. Thin, moderately weak alteration zones, consisting of small anhedral grains of carbonate, quartz, sericite, and rare pyrite, developed around the Stage I veins.

\section{Stage II}

Stage II veins (Figs. 5a-c) consist of quartz, albite, carbonate, and pyrite and are characterized by intense proximal alteration. Carbonate minerals are mainly ankerite, with traces of $\mathrm{Fe}$-dolomite, and rare calcite. The Stage II veins have been found cutting the Stage I quartz-carbonate veins (Fig. 4a). Their width varies from several millimeters to centimeters, and they do not extend over a couple hundred meters. The carbonate minerals tend to crystallize at the edge of the veins (Fig. 5a). Common accessory minerals include rutile, muscovite, apatite, and anhydrite. Anhedral chlorite was found in the interstitial spaces between quartz, albite, and pyrite grains, and probably crystallized from an evolved hydrothermal fluid. The $\sim 8 \%$ sulfide minerals in the Stage II veins are mainly pyrite, with trace chalcopyrite, galena, rare sphalerite, and molybdenite. The pyrite is cubic in shape and can be up to $1 \mathrm{~cm}$ in size. Chalcopyrite is anhedral and fills the interstices between the other minerals. Galena is mostly found enclosed by pyrite, whereas sphalerite and molybdenite have crystallized along the edges of pyrite crystals. Sulfate minerals, such as baryte, celestite, and anhydrite, either co-existed with or were enclosed by pyrite. Brecciated wall rock fragments, up to $\sim 3$ centimeters in size, are found in larger veins and locally can constitute $15 \%$ of the vein. Irregular fine veins $(\sim 1.5 \mathrm{~cm}$ wide $)$ cut through the wall rocks to form stockwork textures (Fig. 5d).

Both hematite and albite alteration are found adjacent to the Stage II veins (Figs. 5a-c), which changes the color of the wallrocks from dark green (the regional metamorphic rock color) to pale, brick red, or yellow. The alteration halo varies in width from $c a$. $2 \mathrm{~cm}$ in the case of small veins (Fig. 5a) to up to two meters for large veins. Tiny anhedral crystals of albite and quartz, found in the albite alteration zone, are interpreted to have crystallized in response to interaction between the auriferous fluid and the wall rocks. Hematite alteration takes two forms: dusty hematite grains on the surface of feldspar, and the microscopic hematite that formed by oxidation of magnetite. Hematite alteration can also be found in association with biotite+chlorite domains (Fig. 5b). However, the mineralized quartz-albite-carbonate-pyrite veins are 

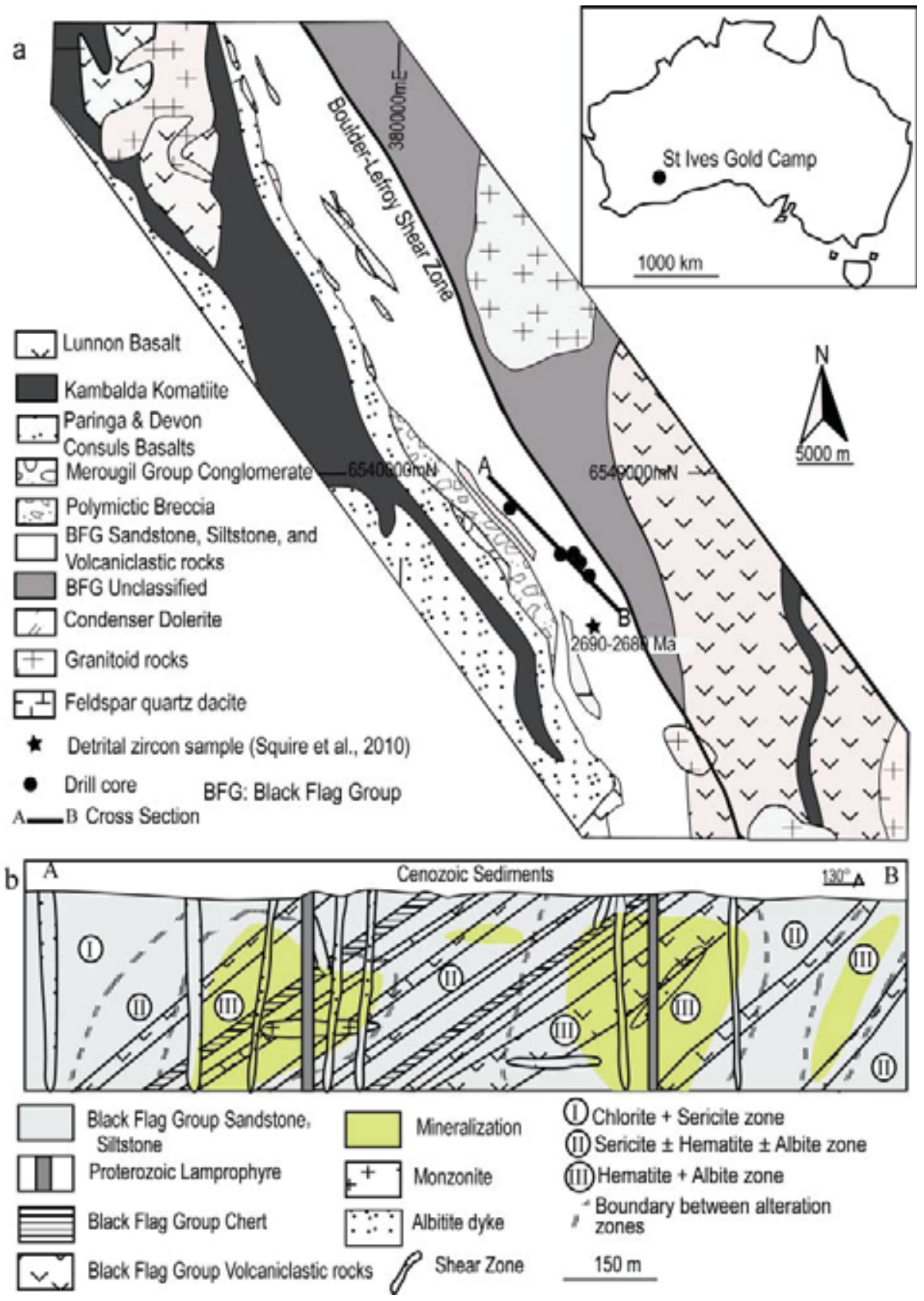

Fig. 1. (a) Geological map of the Bellerophon-Nelson gold deposit. (b) Cross section of the Bellerophon-Nelson gold deposit.

devoid of hematite. The hydrothermal mineral assemblage in the alteration halo is similar to that in the auriferous veins, and includes cubic pyrite, quartz, carbonate, albite, sericite, and apatite.
Stage III

Stage III veins are mainly composed of milky white quartz and pyrite (Figs. 5e-5h), but locally they 


\begin{tabular}{|c|c|c|c|c|}
\hline Mineral assembalge & Stage I & Stage II & Stage III & Stage IV \\
\hline Quartz & & & & \\
\hline Albite & & & & \\
\hline Muscovite & & & & \\
\hline Carbonate & & & & \\
\hline Chlorite & & & & \\
\hline $\begin{array}{l}\text { Apatite } \\
\text { Biotite }\end{array}$ & & & & \\
\hline Rutile & & & & \\
\hline Tourmaline & & & & \\
\hline $\begin{array}{l}\text { Barite } \\
\text { Celestite }\end{array}$ & & & & \\
\hline Anhydrite & & & & \\
\hline Scheelite & & & & \\
\hline Pyrite & & & & \\
\hline Chalcopyrite & & & & \\
\hline Galena & & & & \\
\hline Hematite & & & & \\
\hline Magnetite & & & & \\
\hline Sphalerite & & & & \\
\hline Molybdenite & & - & & \\
\hline Gold & & & & \\
\hline Calaverite & & & & \\
\hline Petzite & & & & \\
\hline Buckhornite & & & & \\
\hline Altaite & & & & \\
\hline $\begin{array}{l}\text { Mielonite } \\
\text { Tellurobismutite }\end{array}$ & & & & \\
\hline Telluroantimony & & & & \\
\hline Rucklidgeite & & & & \\
\hline Aikinite & & & & \\
\hline Tetradymite & & & & \\
\hline $\mathrm{Cl}$-minerals & & - & & \\
\hline Native $\mathrm{Te} / \mathrm{TeO}_{2}$ & & - & & \\
\hline
\end{tabular}

FIG. 2. Paragenesis of the Bellerophon mineral assemblage.

can contain small amounts of carbonate and albite. They cut the Stage II veins (Figs. 4b-4c) and can be up to $2 \mathrm{~m}$ wide, especially those that are composed of almost pure quartz. Wall rock breccias, with fragments of monzonite and albitite dikes, are found in association with Stage III veins (Figs. $5 \mathrm{~g}-5 \mathrm{~h}$ ). Other common accessory minerals in these veins include apatite, rutile, scheelite, and tourmaline. The sulfide minerals $(<\sim 5 \%)$ are cubic pyrite and anhedral chalcopyrite. The sulfate minerals, baryte and celestite, are also found in these veins. Carbonate and albite minerals are mostly found at vein edges as a consequence of a reaction between the vein fluid and wall rocks.
The color of the monzonite, where cut by Stage III veins, is changed from red to light gray or yellow in response to albite alteration (Fig. 5g). Albitite dikes are strongly hematite altered and show both hematite dusting on albite surfaces and microscopically distinct hematite crystals (Fig. 5h). Both albite and hematite alteration are found in the meta-sedimentary and volcaniclastic rocks surrounding the quartz-pyrite veins. Locally, there are clear reaction zones between the quartz-pyrite-carbonate veins and wall rocks (Fig. 5f) that have resulted in the crystallization of carbonate, albite, quartz, scheelite, muscovite, pyrite, and native gold. 


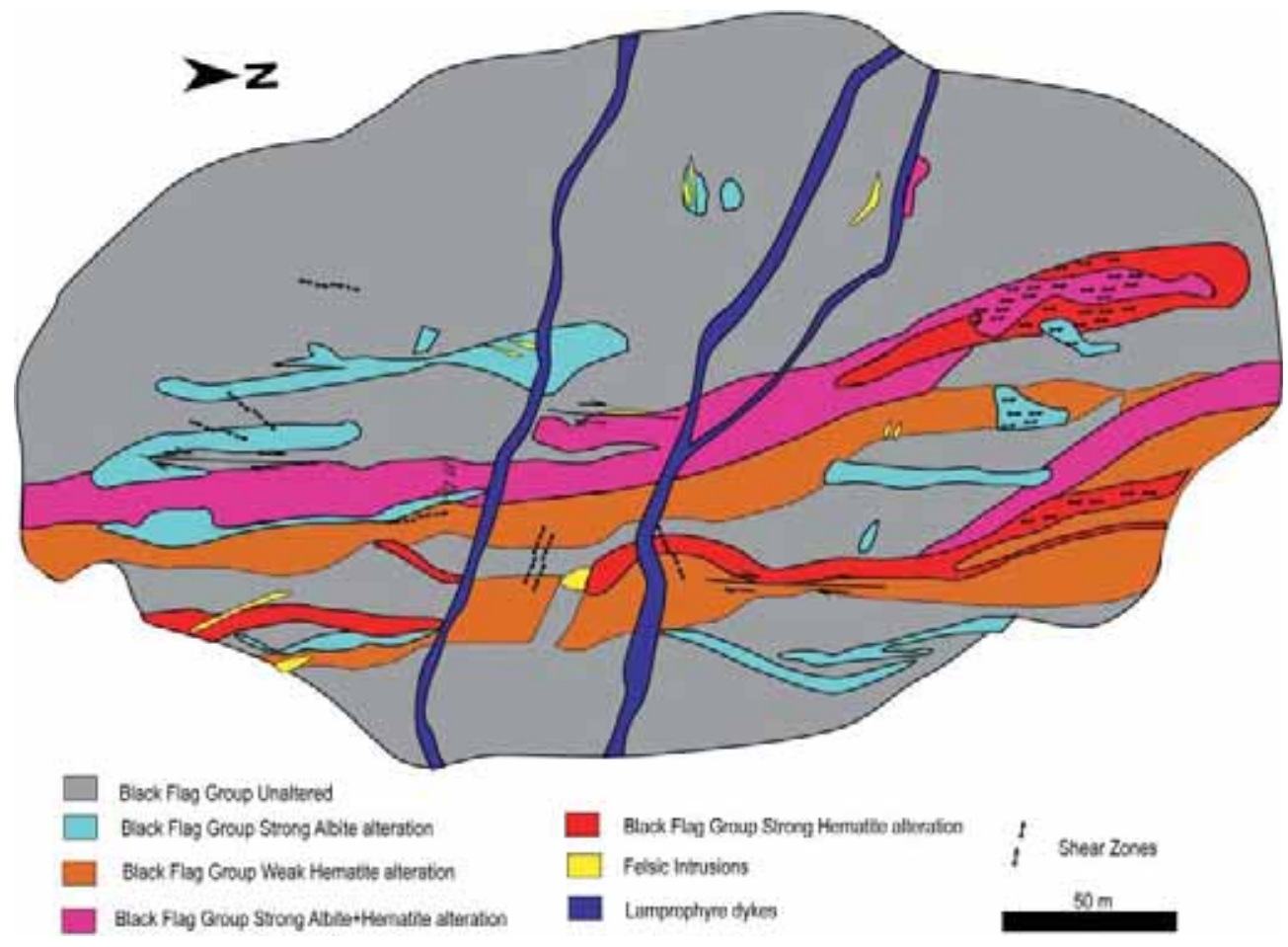

FIG. 3. Geological map of the Bellerophon deposit.

\section{Stage IV}

There are two types of Stage IV veins: carbonate-chlorite veins and carbonate veins. The former can cut the latter and both are younger than Stage II and Stage III veins (Figs. 4b-c). The Stage IV veins are thin, with widths of no more than $5 \mathrm{~mm}$. Minor minerals, which make up less than $15 \%$ of the veins, include quartz, pyrite, muscovite, biotite, magnetite, and tourmaline. The proportion of these minerals varies: some veins have tourmaline and pyrite, whereas others contain muscovite or magnetite (the magnetite locally altered to hematite). Wall rocks for the Stage IV veins are sedimentary and volcaniclastic rocks. There is no alteration halo surrounding the Stage IV veins, other than disseminated chlorite and carbonate minerals in wall rocks close to the veins.

\section{Mineralized sericite-pyrite seams}

Another type of mineralization that has been observed at Bellerophon takes the form of native gold and telluride minerals, which occur in sheared sericitepyrite seams. These seams have a width of several centimeters, are tens of centimeters in length, and are oriented sub-parallel to the foliation in the wall rocks.
Mineralized sericite-pyrite seams can be found in the quartz-pyrite veins as stringers (Fig. 5i). Muscovite grains are strongly aligned within the seams. The smaller grains of sericite, with sizes of up to tens of $\mu \mathrm{m}$, are interpreted to be inherited from the primary fabric of the rocks, which indicate their metamorphic origin. In contrast, larger examples, with grain sizes up to $0.5 \mathrm{~mm}$, are thought to have re-crystallized during mineralization. Pyrite is subhedral to anhedral and can be elongated with curvilinear boundaries (Fig. 5j). These features, combined with the pressure shadow textures between pyrite and fringed biotite + sericite + quartz, were produced by ductile deformation of the shear zones. Besides sericite and pyrite, other trace minerals in the mineralized sericite-pyrite seams include biotite, carbonate, rutile, locally chlorite, and small grains of albite. Elongated pyrite crystals enclose various minerals, including carbonate, sericite, native gold, tellurides, chalcopyrite, and pyrrhotite. The carbonate and sericite grains are usually found in the rim zone of the pyrite, and have the same microscope features as these minerals in the re-crystallized carbonate-sericite seams. These textures indicate that the pyrite was dissolved and re-crystallized during mineralization. Grains of pyrrhotite are not found in the auriferous veins and are therefore interpreted to be inherited from the precursor rocks. 

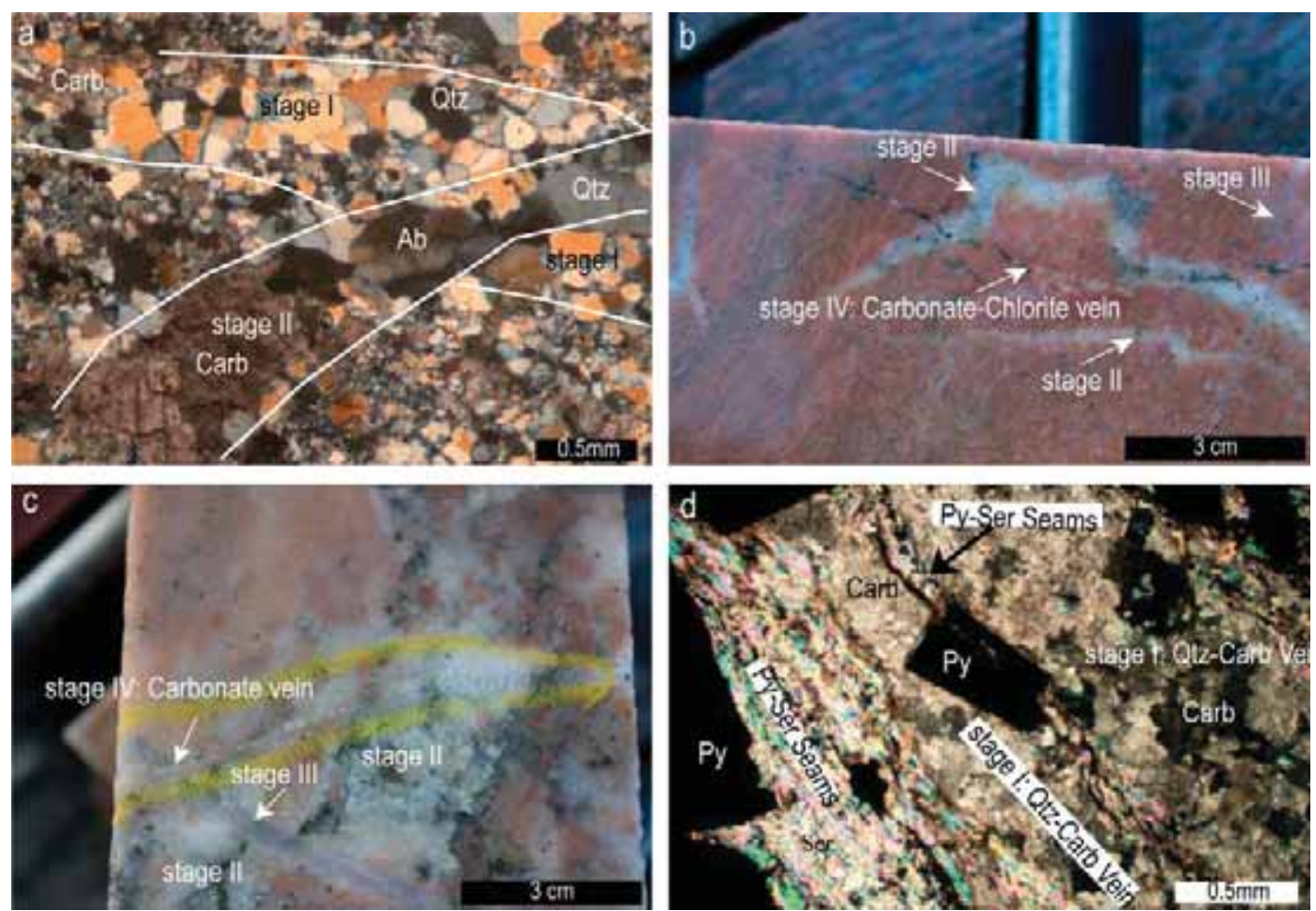

FIG. 4. Cross-cutting relationships between veins. (a) A Stage II vein cuts an earlier Stage I quartz-carbonate vein. (b), (c) Cross-cutting relations between Stage II, Stage III, and Stage IV veins. (d) Pyrite-sericite sheared seams cuts pyrite in a Stage I quartz-carbonate vein. Ab = albite; Carb = carbonate; Py = pyrite; Qtz = quartz; Ser = sericite.

The broken Stage I pyrite crystal seen in Figure $4 \mathrm{~d}$ shows that the pyrite-sericite seams that fill the pyrite fractures are later than the Stage I veins. The pyrite-sericite seams and quartz-albite-carbonate-pyrite veins have similar telluride mineralogy, which suggests that they crystallized under conditions of similar $\mathrm{fS}_{2} \mathrm{fTe}_{2}$ as discussed below, and indicate that the pyrite-sericite seams belong to Stage II. Furthermore, native gold grains have been found in breccias in the Stage II veins, indicating brittle deformation, whereas the elongated pyrite crystals in the sericite-pyrite seams are interpreted to be the product of ductile deformation. Therefore, ductile and brittle deformation occurred over the same time interval, and both were coeval with gold mineralization.

\section{Systematic changes of the magnetic susceptibility}

Alteration haloes around the Bellerophon veins show a systematic variation in magnetic susceptibility. An example is illustrated in Figure 6a, which shows a ca. $15 \mathrm{~cm}$-wide hematite alteration halo adjacent to an auriferous vein. Magnetic susceptibility gradually increases from $<1.0$ (the dimensionless ratio of the magnetic moment per unit volume to the magnetic field strength) in the hematite alteration to up to $>10.0$ in precursor rocks. The hematite-altered rock shown in Figure $6 \mathrm{~b}$ has magnetic susceptibility values as high as 22.6 , whereas it is only 0.6 in the adjacent chlorite alteration zone. The magnetic susceptibility for hematite in altered rocks can vary from $\sim 1.0$ to $\sim 50$; for precursor rocks, the values can be between 10 and $>100$. The albitite dike rocks are strongly hematite altered (Fig. 5h), and magnetic susceptibility values generally lie between 15 and $\sim 30$.

The hematite- and albite-altered samples in Figure $6 \mathrm{c}$ are in close proximity to each other and associated with similar Stage II mineralized veins. However, the magnetic susceptibility value of the hematite-altered rock is 25 times higher than that of the albite-altered rock. Generally, the magnetic susceptibility value in albite-altered rocks is $<1$, and the values for the precursor rocks to albite alteration are in the same range as that of albite alteration. For instance, the magnetic susceptibility values for both fresh and albite-altered monzonite rocks are $\sim 0.5$. Furthermore, the magnetic susceptibility values of albite+hematite-altered rocks generally have large overlaps with those of both the hematite alteration and albite alteration. 
THE CANADIAN MINERALOGIST

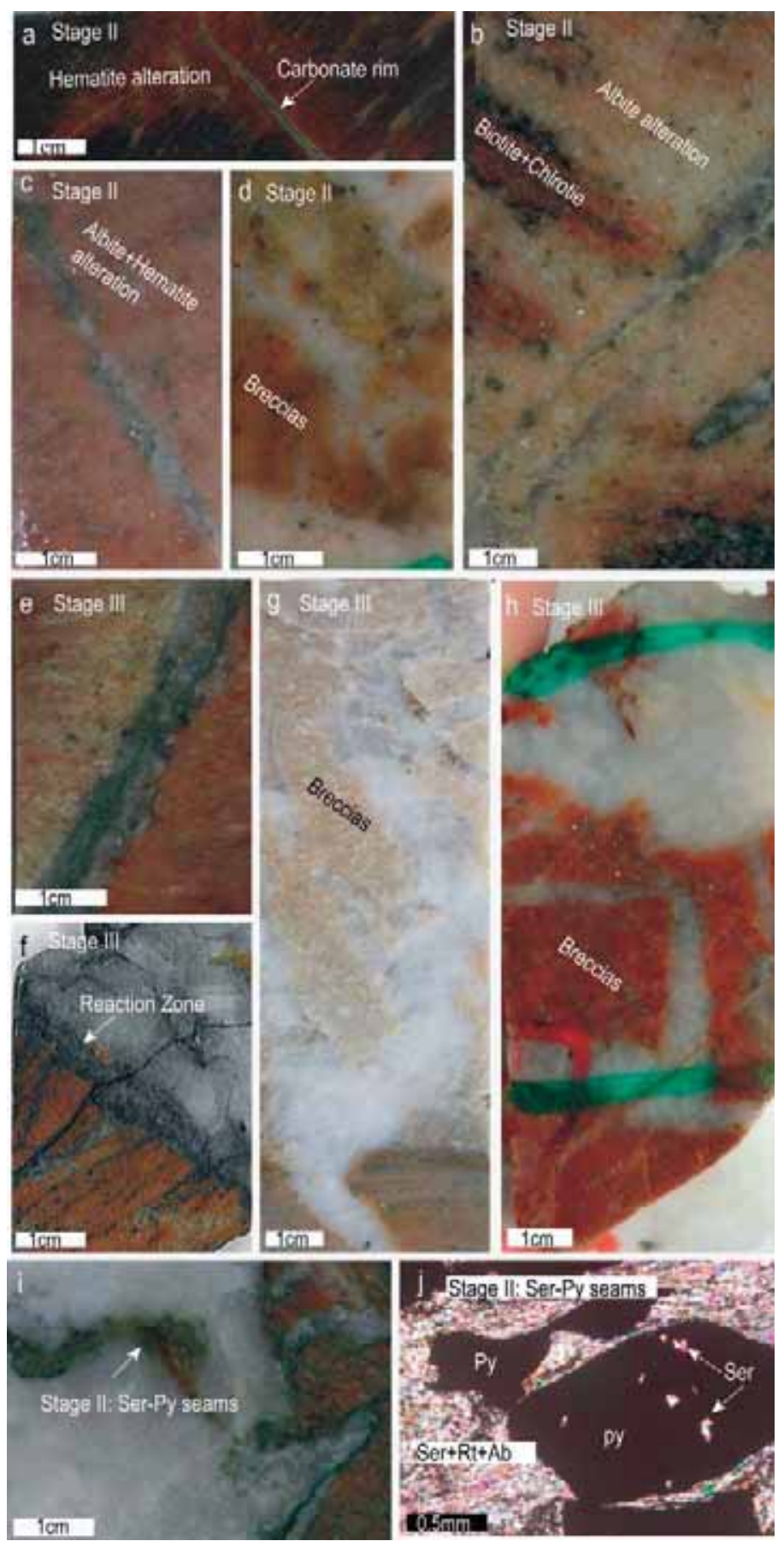




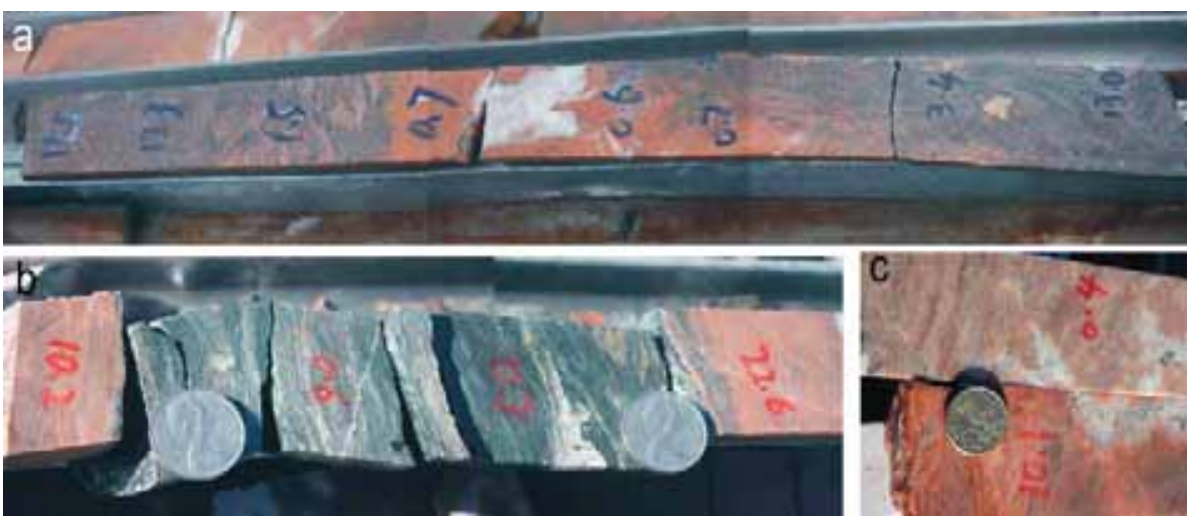

FIG. 6. (a) Variation in magnetic susceptibility of unaltered rocks and rocks that have undergone hematite alteration. (b) The sharp contrast of magnetic susceptibility values for rocks that have undergone hematite alteration and adjacent zones of chlorite alteration. (c) A comparison of the magnetic susceptibility values between hematite alteration and the proximal albite alteration zones.

\section{Native Gold, Telluride, Sulfosalt and Cl-Bearing Minerals}

Thirteen telluride sulfosalt and chlorine-bearing minerals have been identified in the mineralized Stage II and III rocks, of which calaverite, petzite, tellurobismuthite, and altaite are the most common. Other minerals include melonite, telluroantimony, rucklidgeite, tetradymite, buckhornite, aikinite, and native tellurium. The Cl-bearing minerals are associated with native tellurium or Te-oxide, and consist of $\mathrm{Bi}-\mathrm{Cl}$ and $\mathrm{Pb}-\mathrm{Cl}$ oxide or hydroxide minerals.

\section{Native gold}

Native gold has three different types of occurrence at Bellerophon. The first is found in mineralized veins, i.e., quartz-albite-carbonate-pyrite veins from Stage II and quartz-pyrite veins from Stage III. The second is in the sericite-pyrite seams. Finally, small grains of gold are locally enclosed by pyrite in intensely altered wall rocks. Representative compositions of native gold are listed in Table 1.
Native gold is either intergrown with pyrite or quartz in the quartz-albite-carbonate-pyrite veins, or enclosed by pyrite and rarely by albite (Fig. 7a). Alternatively, it may fill fractures in pyrite (Fig. 8a). The size of the gold grains varies from several $\mu \mathrm{m}$ up to $100 \mu \mathrm{m}$. Some grains of pyrite have dusty textures with abundant inclusions that consist mainly of rutile with trace amounts of gold + calaverite (Fig. 7a). The finesse of native gold in the quartz-albite-carbonatepyrite veins is always higher than 900 (Table 1). In the quartz-pyrite veins, native gold is either enclosed by pyrite or disseminated in the veins with telluride minerals (Fig. 7b, 7f). The size of these gold grains is $20-50 \mu \mathrm{m}$, and the finesse is highly variable, from as high as 960 down to as low as 800 (Table 1). Gold grains enclosed by pyrite have higher values of finesse than the free gold in the quartz-pyrite veins. Gold grains in the pyrite-sericite seams are enclosed by pyrite (Fig. 7c and 7d) or fill extension fractures in pyrite (Fig. 8b). Some gold grains form films that crystallized along the edges of pyrite grains in association with sericite. Native gold in the sericite-pyrite seams is generally a few $\mu \mathrm{m}$ in size, and the finesse is mainly in the range of $900 \sim 950$.

FIG. 5. (a) Native gold and telluride minerals in a quartz-albite-carbonate-pyrite vein with a hematite alteration halo. (b) A quartz-albite-carbonate-pyrite vein mantled by albite and hematite alteration. Note that the hematite alteration is associated with biotite-chlorite domains. (c) A quartz-albite-carbonate-pyrite vein with the albite+hematite alteration halo. (d) Quartzalbite-carbonate-breccia texture in a Stage II vein. (e) A quartz-pyrite vein with albite+hematite and hematite alteration halos. Abundant gold and telluride minerals are found in this vein. (f) Quartz veins cutting the primary foliation. Native gold, albite, pyrite, muscovite, and scheelite have precipitated in the dark reaction zone. (g) A quartz-pyrite vein cutting a monzonite intrusion and forming a stockwork texture. The monzonite shows intense albite alteration, and gold grades can be as high as $16 \mathrm{ppm}$. (h) Stockwork texture in a quartz-pyrite vein within an albitite dyke rock. (i) Stringers of sericitepyrite seams in a late white quartz vein. The stringer contains native gold and telluride minerals. (j) Curvilinear boundaries of pyrite in sericite-pyrite seams. Sericite inclusions and pressure shadows are found in association with these pyrite grains. 


\section{Calaverite}

Calaverite was deposited in the Stage II and III veins, but was not found in the sericite-pyrite seams. It is bright and light yellow under reflected light and its shape varies from subhedral to anhedral. The size of the crystals is usually small, typically $<20 \mu \mathrm{m}$. Calaverite is typically associated with albite and carbonate in the quartz-albite-carbonate-pyrite veins. Inclusions of calaverite have been found in pyrite (Fig. 7a) and rarely in albite (Fig. 7e) where they have curvilinear boundaries (Fig. 7e). In the quartz-pyrite veins, it is disseminated and associated with other precious minerals (Fig. 7b). Unlike native gold, the surface of calaverite is highly porous (Fig. 7b), which may explain why the totals for the SEM analyses are generally near $97 \%$. The composition of calaverite is given in Table 1, and its formula is approximately $\mathrm{AuTe}_{(1.97 \sim 2.08)}$. Apart from 0.4 to $0.9 \% \mathrm{Ag}$, no other trace element was detected.

\section{Petzite}

Petzite has been found in both the quartz-pyrite veins and sericite-pyrite seams, but not in the quartzalbite-carbonate-pyrite veins. Two types occur in the quartz-pyrite veins based on size: the larger grains (near $20 \mu \mathrm{m}$ ) are usually subhedral, whereas smaller petzite crystals have a grain size of only a couple of microns (Fig. 7f). Furthermore, the small grains always form trails that fill fractures in quartz and are connected with larger grains of petzite (Fig. 7f). Petzite in the sericite-pyrite seams can be either

FIG. 7. (a) Zoned pyrite crystal in a quartz-albite-carbonatepyrite vein, with an inner zone of dusty pyrite that contains inclusions of rutile $(\mathrm{Rt})+$ native gold $(\mathrm{Au})+$ calaverite (Clv), and an outer zone of pyrite. (b) Mineral association of native gold, calaverite, petzite (Ptz), and tellurobismuthite $(\mathrm{Tb})$ in a quartz-pyrite vein. Note the porous texture on the surface of calaverite, petzite, and tellurobismuthite grains. (c) A mineral assemblage of native gold, galena $(\mathrm{Gn})$, tellurobismuthite, buckhornite (Buh), and chalcopyrite $(\mathrm{Cp})$ enclosed by pyrite in a sericite-pyrite seam. (d) An association of native gold, petzite, melonite (Mlt), and rucklidgeite (Ruc) enclosed by pyrite in a sericite-pyrite seam; altaite (Alt) can fill fractures in pyrite. Note that melonite occurs in the middle of petzite. (e) Rounded grains of calaverite with curvilinear boundaries enclosed by albite in a quartz-albite-carbonate-pyrite vein. (f) Native gold and petzite in a quartz-pyrite vein. Note the trails of small petzite crystals associated with larger petzite grains. (g) Galena and aikinite (Aik) enclosed by pyrite in a quartz-albite-carbonate-pyrite vein. The relations between galena and aikinite indicate exsolution or an immiscibility reaction. (h) Buckhornite associated with chalcopyrite and galena in disseminated pyrite from an albite altered rock next to a mineralized vein. 

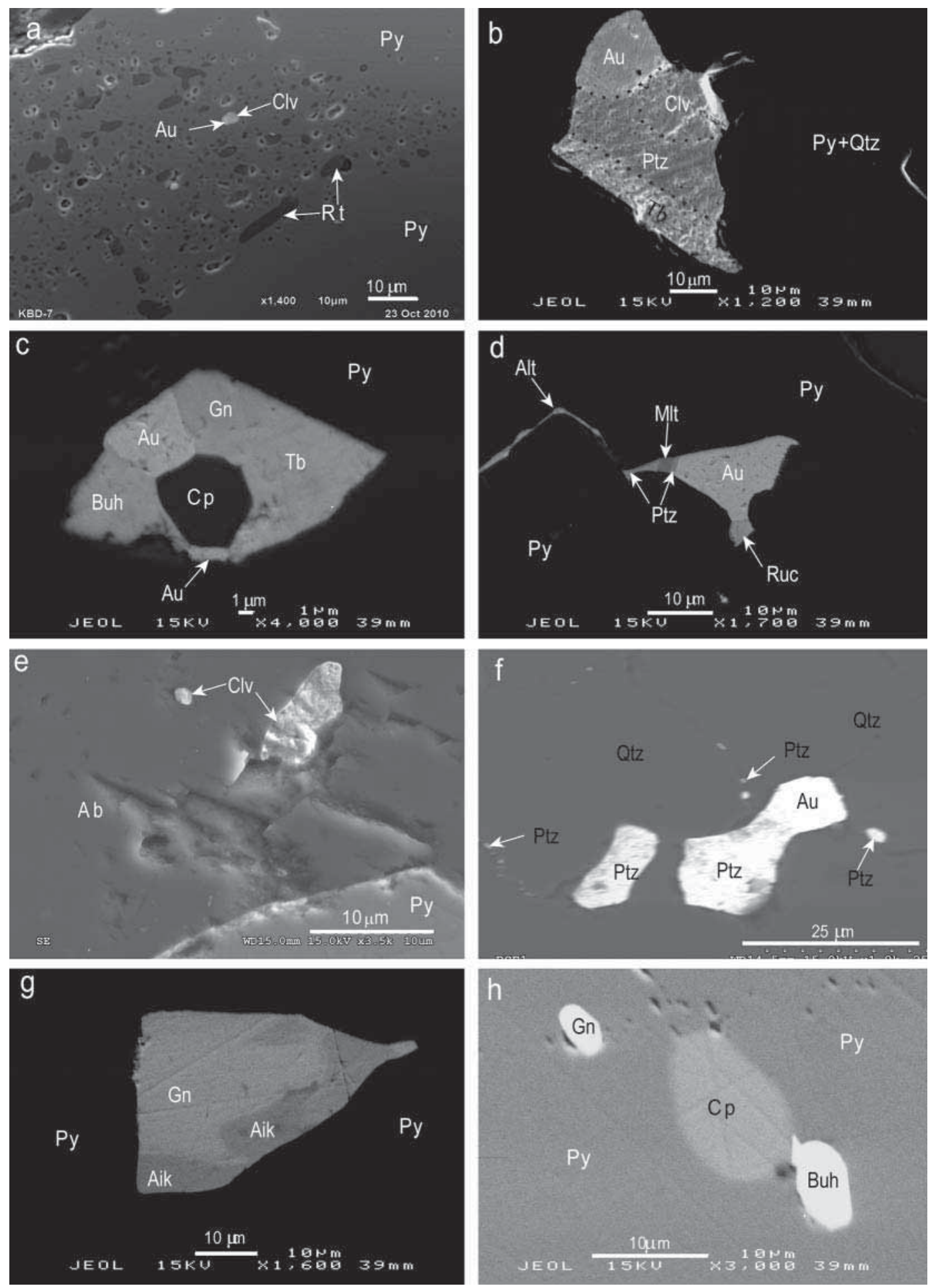

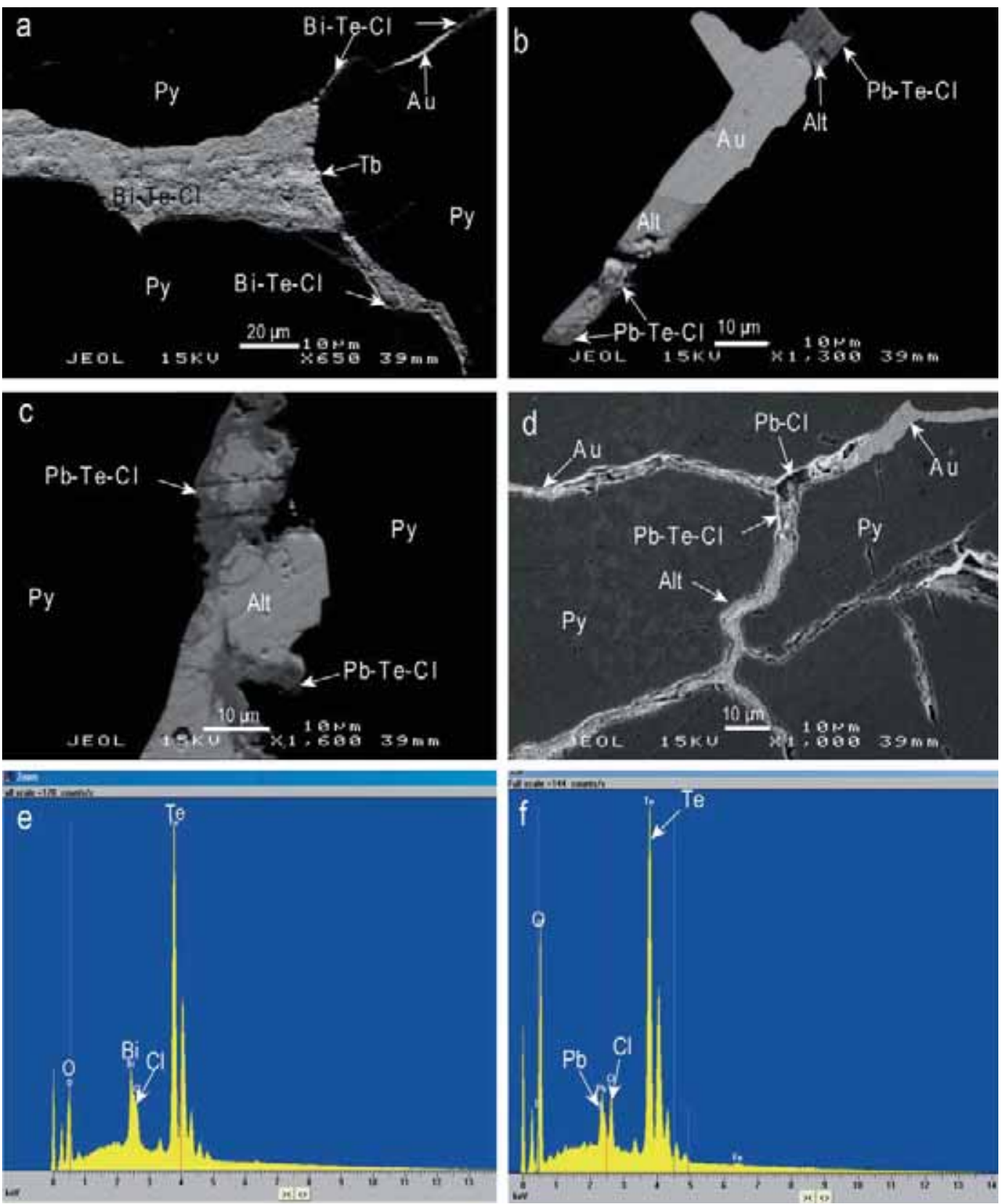

FIG. 8. (a) Mineral assemblage consisting of Bi-Cl-Te, telluriobismuthite ( $\mathrm{Tb}$ ), and native gold filling fractures in pyrite in a sheared sericite-pyrite seam. Note that the Bi-Cl-Te area is a mixture of native $\mathrm{Te}$ and $\mathrm{Bi}-\mathrm{Cl}$ minerals, which replaces telluriobismuthite $(\mathrm{Tb})$. The microphotograph also shows native gold associated with Bi-Cl-Te. (b) Native gold and altaite (Alt) filling a fracture in pyrite from a pyrite-carbonate-quartz-albite vein. The area of $\mathrm{Pb}-\mathrm{Cl}-\mathrm{Te}$, which replace altaite, is a mixture between native tellurium and $\mathrm{Pb}-\mathrm{Cl}$ minerals. (c) An altaite and $\mathrm{Pb}-\mathrm{Cl}$ - $\mathrm{Te}$ mixture filling a fracture in pyrite from a quartz-carbonate-albite-pyrite vein; the altaite was replaced by $\mathrm{Pb}-\mathrm{Cl}-\mathrm{Te}$. (d) $\mathrm{An}$ assemblage of native gold, $\mathrm{Pb}-\mathrm{Cl}$ minerals, $\mathrm{Pb}-\mathrm{Cl}-\mathrm{Te}$ mixture, and altaite filling fractures in pyrite in a quartz-albite-carbonate-pyrite vein. Note that the $\mathrm{Pb}-\mathrm{Cl}$ mineral has precipitated next to native gold, and that the $\mathrm{Pb}-\mathrm{Cl}-\mathrm{Te}$ minerals occur between $\mathrm{Pb}-\mathrm{Cl}$ and altaite. (e) Element spectra diagram of Bi-Cl-Te minerals from a sericite-pyrite seam. (f) Element spectra for the $\mathrm{Pb}-\mathrm{Cl}-\mathrm{Te}$ minerals from a quartz-albite-carbonate-pyrite vein. 
intergrown with sericite or enclosed by pyrite in association with native gold (Fig. 7d). The surface of petzite is porous (Fig. 7b) and, as a consequence, the SEM analyses totals fall below $100 \%$. It has low $\mathrm{Ag}$ but high Te (Table 1) with the approximate formula $\mathrm{Au}_{0.98 \sim 1.09} \mathrm{Ag}_{2.87 \sim 2.95} \mathrm{Te}_{2.03 \sim 2.07}$.

Altaite

Altaite is found in both the quartz-albite-pyritecarbonate veins and sericite-pyrite seams. In the former, altaite fills fractures in pyrite and must therefore be later than pyrite and albite (Fig. 8a, c, d). Altaite in the sericite-pyrite seams fills fractures in pyrite together with petzite and native gold (Fig. 7d). Euhedral laths of altaite were also found in sheared seams intergrown with sericite, albite, and native gold. The atomic percentage of $\mathrm{Pb}$ is normally 1 to $5 \%$ less than $\mathrm{Te}$. Bismuth can substitute $\mathrm{Pb}$ in altaite and the atomic percentage can be as high as $11 \%$ (Table 2).

\section{Tellurobismuthite}

Tellurobismuthite $\left(\mathrm{Bi}_{2} \mathrm{Te}_{3}\right)$ is the only Bi-telluride mineral found in the Bellerophon deposit. Subhedraleuhedral grains, with a size of around $20 \mu \mathrm{m}$, are found associated with native gold, carbonate, and albite in the quartz-albite-carbonate-pyrite veins. It can also fill fractures in pyrite in association with altaite. Tellurobismuthite in quartz-pyrite veins is normally associated with gold and calaverite (Fig. 7b). It is also found intergrown with chalcopyrite as inclusions in quartz in quartz-pyrite veins. Tellurobismuthite in sericite-pyrite seams is either enclosed by pyrite (Fig. 7c) or fills fractures in pyrite. The analyzed tellurobismuthite has the formula $\mathrm{Bi}_{1.94 \sim 1.97} \mathrm{Te}_{3.01 \sim 3.06}$ (Table 2).

Two other telluride minerals found in this study were melonite $\left(\mathrm{NiTe}_{2}\right)$ and telluroantimony $\left(\mathrm{Sb}_{2} \mathrm{Te}_{3}\right)$. Melonite was found in both quartz-albite-carbonatepyrite veins and sericite-pyrite seams (Fig. 7d). Melonite in Bellerophon contains $\mathrm{Fe}$, with the composition of $\left(\mathrm{Ni}_{0.9}, \mathrm{Fe}_{0.1}\right) \mathrm{Te}_{2}$. Tellurantimony was only found in the sericite-pyrite seams and it is enriched in tellurium relative to antimony compared with the stoichiometric formula.

\section{Sulfosalt minerals}

The sulfosalt minerals found at Bellerophon include rucklidgeite $\left(\mathrm{Pb}_{1} \mathrm{Bi}_{2} \mathrm{Te}_{4}\right)$, buckhornite $\left[\mathrm{Au}_{1}\left(\mathrm{~Pb}_{2} \mathrm{Bi}_{1}\right)_{3}\right.$ $\left.\mathrm{Te}_{2} \mathrm{~S}_{3}\right]$, aikinite $\left[\left(\mathrm{Cu}_{1}, \mathrm{~Pb}_{1}, \mathrm{Bi}_{1}\right) \mathrm{S}_{3}\right]$, and tetradymite $\left(\mathrm{Bi}_{2} \mathrm{Te}_{2} \mathrm{~S}_{1}\right)$; the compositions are listed in Tables 2 and 3. Tetradymite and buckhornite are the most common. Only one grain of rucklidgeite was found in a sericite-pyrite seam, and aikinite was only found in quartz-albite-carbonate-pyrite veins where it was 
TABLE 3. REPRESENTATIVE COMPOSITIONS OF BUCKHORNITE AND AIKINITE

\begin{tabular}{|c|c|c|c|c|c|c|c|c|}
\hline \multirow[b]{2}{*}{ type } & \multicolumn{6}{|c|}{ Buckhornite } & \multicolumn{2}{|c|}{ Aikinite } \\
\hline & Vein 1 & Vein 1 & Vein 1 & Vein 1 & Ser-Py & Ser-Py & Vein 1 & Vein 1 \\
\hline $\mathrm{Au}$ (wt.\%) & 16.80 & 16.60 & 16.69 & 16.68 & 17.27 & 16.47 & & \\
\hline $\mathrm{Cu}$ & & & & & & & 8.26 & 9.37 \\
\hline $\mathrm{Pb}$ & 36.60 & 37.66 & 35.97 & 36.87 & 37.64 & 36.91 & 34.13 & 36.05 \\
\hline $\mathrm{Bi}$ & 14.65 & 13.95 & 15.51 & 15.30 & 14.86 & 14.49 & 38.26 & 36.54 \\
\hline $\mathrm{Te}$ & 21.64 & 21.24 & 21.71 & 21.47 & 21.96 & 21.77 & & \\
\hline $\mathrm{Ag}$ & & & & & & & 0.14 & 0.16 \\
\hline$S$ & 7.55 & 7.16 & 7.94 & 7.69 & 7.94 & 8.15 & 15.61 & 15.83 \\
\hline Total & 97.24 & 96.61 & 97.82 & 98.01 & 99.67 & 97.79 & 96.40 & 97.95 \\
\hline Au (formula) & 1.04 & 1.05 & 1.02 & 1.02 & 1.04 & 0.99 & & \\
\hline $\mathrm{Cu}$ & & & & & & & 0.27 & 0.30 \\
\hline $\mathrm{Pb}$ & 2.16 & 2.26 & 2.08 & 2.15 & 2.15 & 2.12 & 0.34 & 0.35 \\
\hline $\mathrm{Bi}$ & 0.86 & 0.83 & 0.89 & 0.88 & 0.84 & 0.82 & 0.38 & 0.35 \\
\hline $\mathrm{Te}$ & 2.07 & 2.07 & 2.04 & 2.03 & 2.04 & 2.03 & & \\
\hline $\mathrm{Ag}$ & & & & & & & 0.00 & 0.00 \\
\hline$S$ & 2.88 & 2.78 & 2.97 & 2.90 & 2.94 & 3.03 & 1.01 & 1.00 \\
\hline
\end{tabular}

enclosed by pyrite and associated with galena (Fig. 7g).

Buckhornite inclusions in pyrite were found in quartz-albite-carbonate-pyrite veins, sericite-pyrite sheared seams, and mineralized wall rocks (Fig. 7h). Most buckhornite grains are rounded with curvilinear boundaries, but some are euhedral with rhombic shapes. The size of buckhornite grains can be up to $\sim 30 \mu \mathrm{m}$. Tetradymite, in association with altaite, fills fractures in pyrite from the mineralized veins. Small grains of tetradymite were also found in sericite-pyrite seams. As shown in Table 2, tetradymite from the Bellerophon deposit is enriched in tellurium and depleted in sulfur.

\section{Native Te/Te-oxide and chlorine bearing minerals}

Native Te/Te-oxide and Cl-bearing minerals have been found in the Bellerophon deposit (Fig. 8). The Cl-bearing minerals are divided into two groups, those that belong to the $\mathrm{Pb}-\mathrm{Cl}$ system of minerals and those that belong to the $\mathrm{Bi}-\mathrm{Cl}$ system. The $\mathrm{Pb}-\mathrm{Cl}$ minerals have only been found in the mineralized quartz-albite-carbonate-pyrite veins (Fig. 8a, c, d), and the $\mathrm{Bi}-\mathrm{Cl}$ minerals in the sericite-pyrite seams (Fig. 8b). Native Te/Te-oxide occurs intergrown with both. Altaite has been found associated with $\mathrm{Pb}-\mathrm{Cl}$ minerals, and tellurobismuthite with $\mathrm{Bi}-\mathrm{Cl}$ minerals. Native gold locally occurs intergrown with both $\mathrm{Bi}-\mathrm{Cl}$ and $\mathrm{Pb}-\mathrm{Cl}$ minerals (Fig. 8). Chlorine-bearing minerals are among the last to crystallize, as they fill fractures in pyrite and replace other telluride minerals (Fig. 8). During the replacement process, invisible
$\mathrm{Au}$ in telluride minerals was reactivated and precipitated with the Cl-bearing minerals in pyrite fractures. Tellurium/Te-oxide and Cl-bearing minerals are always mixed together, and cannot be distinguished under the microscope (Fig. 8a, c). Therefore, they are described together here.

The surface of these $\mathrm{Bi}-\mathrm{Cl}-\mathrm{Te}$ and $\mathrm{Pb}-\mathrm{Cl}-\mathrm{Te}$ minerals is porous, as shown in Figure 8, and the compositions are listed in Table 4 . The atomic percentage of $\mathrm{Te}$ in the $\mathrm{Pb}-\mathrm{Cl}-\mathrm{Te}$ system minerals lies within the range 19.5 84.0\%, whereas the values for $\mathrm{Pb}$ and $\mathrm{Cl}$ lie between $4.6 \sim 36.3 \%$ and $10.0 \sim 41.4 \%$ respectively, which indicates a mixture between native Te/Te-oxide and $\mathrm{Pb}-\mathrm{Cl}$. This is the same as for the $\mathrm{Bi}-\mathrm{Cl}-\mathrm{Te}$ system minerals. Element spectra diagrams for $\mathrm{Pb}-\mathrm{Cl}$ and $\mathrm{Bi}-\mathrm{Cl}$ minerals show obvious oxygen peaks that can be higher than the $\mathrm{Cl}$ and $\mathrm{Bi}$ peaks (Fig. 8e, 8f), which could be the reason for the low analytical totals in Table 4. The Cl-bearing minerals are interpreted to be of the form $\mathrm{PbCl}(\mathrm{OH})_{x}$ and $\mathrm{BiCl}(\mathrm{OH})_{x}$. As shown in Table 4 , the atom ratios of $\mathrm{Pb} / \mathrm{Cl}$ and $\mathrm{Bi} / \mathrm{Cl}$ range from 0.85 to 1.02 and 0.94 to 1.18 , respectively. Therefore, the $\mathrm{PbCl}(\mathrm{OH})_{x}$ mineral can be a mixture between laurionite/paralaurionite $[\mathrm{PbCl}(\mathrm{OH})]$ and penfieldite $\left[\mathrm{Pb}_{2} \mathrm{Cl}_{3}(\mathrm{OH})\right]$, and the $\mathrm{BiCl}(\mathrm{OH})_{x}$ mineral should be a mixture between bismoclite $(\mathrm{BiOCl})$ and daubreeite $[\mathrm{BiO}(\mathrm{OH}, \mathrm{Cl})]$. After calculated $(\mathrm{OH})$ is added to the SEM analytical total, the final results are still below $100 \%$, which suggests that there should be tellurite $\left(\mathrm{TeO}_{2}\right)$ instead of native Te. However, if all of the $\mathrm{Te}$ was present as $\mathrm{TeO}_{2}$ the totals would be over $100 \%$. We conclude that $\mathrm{Pb}-\mathrm{Cl}-$ $\mathrm{Te}-(\mathrm{OH})$ system minerals are mixtures of $\mathrm{PbCl}(\mathrm{OH})$, 
TABLE 4. REPRESENTATIVE COMPOSITIONS OF Bi-Te-CI SYSTEM AND Pb-Te-CI SYSTEM MINERALS

\begin{tabular}{|c|c|c|c|c|c|c|c|c|c|c|c|c|}
\hline \multirow[b]{2}{*}{ type } & \multicolumn{4}{|c|}{$\mathrm{Pb}-\mathrm{Te}-\mathrm{Cl}$ system minerals } & \multicolumn{8}{|c|}{$\mathrm{Bi}-\mathrm{Te}-\mathrm{Cl}$ system minerals } \\
\hline & Vein 1 & Vein 1 & Vein 1 & Vein 1 & Ser-Py & Ser-Py & Ser-Py & Ser-Py & Ser-Py & Ser-Py & Ser-Py & Ser-Py \\
\hline Te (wt.\% & 41.85 & 51.57 & 18.14 & 0.16 & 82.92 & 73.73 & 68.17 & 79.33 & 65.52 & 66.68 & 71.46 & 77.46 \\
\hline $\mathrm{Bi}$ & & & & & 6.72 & 14.11 & 23.89 & 12.32 & 26.99 & 22.91 & 18.49 & 11.47 \\
\hline $\mathrm{Pb}$ & 38.09 & 29.91 & 54.72 & 70.87 & & & & & & & & \\
\hline $\mathrm{Cl}$ & 7.72 & 6.02 & 10.68 & 11.87 & 1.21 & 2.40 & 3.49 & 1.78 & 4.02 & 3.36 & 2.91 & 1.72 \\
\hline Total & 87.66 & 87.50 & 83.54 & 82.90 & 90.85 & 90.24 & 95.55 & 93.43 & 96.53 & 92.95 & 92.86 & 90.65 \\
\hline Te (at.\% & 44.96 & 56.27 & 20.10 & 0.18 & 90.75 & 81.05 & 71.53 & 85.07 & 67.93 & 71.90 & 76.67 & 85.45 \\
\hline $\mathrm{Bi}$ & & & & & 4.49 & 9.47 & 15.30 & 8.07 & 17.09 & 15.08 & 12.11 & 7.73 \\
\hline $\mathrm{Pb}$ & 25.23 & 20.12 & 37.37 & 50.50 & & & & & & & & \\
\hline $\mathrm{Cl}$ & 29.81 & 23.61 & 42.53 & 49.32 & 4.76 & 9.48 & 13.16 & 6.86 & 14.98 & 13.02 & 11.22 & 6.82 \\
\hline $\mathrm{Bi}, \mathrm{Pb} / \mathrm{Cl}$ & 0.85 & 0.85 & 0.88 & 1.02 & 0.94 & 1.00 & 1.16 & 1.18 & 1.14 & 1.16 & 1.08 & 1.13 \\
\hline
\end{tabular}

$\mathrm{Pb}_{2} \mathrm{Cl}_{3}(\mathrm{OH})$, native $\mathrm{Te}$, and $\mathrm{TeO}_{2}$; and the $\mathrm{Bi}-\mathrm{Cl}-\mathrm{Te}-$ $(\mathrm{OH})$ minerals are mixtures of $\mathrm{BiOCl}, \mathrm{BiO}(\mathrm{OH}, \mathrm{Cl})$, native $\mathrm{Te}$, and $\mathrm{TeO}_{2}$.

\section{DisCUSSION}

\section{Hematite and albite alteration}

The two most prominent types of alteration found adjacent to the mineralized veins at Bellerophon are hematite and albite alteration, and both types can be mineralized. Hematite alteration is found in the albitite dike rocks, and intense albite alteration has also been found in monzonite intrusions. Intense hematite and albite alteration occurs in both meta-sedimentary and volcaniclastic rocks. Both the nature of the hydrothermal fluid and precursor rocks affect the type of alteration. A study of the temporal and spatial relations between alteration and mineralization, and causes of the observed differences, is essential to understand the mineralization process.

We interpret the hematite and albite alterations to be coeval and derived from the same hydrothermal fluid. The evidence to support this interpretation can be summarized follows: (1) quartz-albite-carbonate-pyrite veins can be associated with both intense albite alteration and hematite alteration in the meta-sedimentary rocks (Fig. 5a, 5b); (2) quartz-pyrite veins can be associated with albite alteration in monzonite intrusions and hematite alteration in albitite dike rocks; (3) intense albite + hematite alteration, which has features of both the albite alteration and hematite alteration, has been observed; (4) hematite alteration implies that the hydrothermal fluid was highly oxidized (Neumayr et al. 2008). The sulfate minerals, baryte and celestite, have been found in the veins which are associated with albite alteration. Therefore, both types of alteration were caused by highly oxidized fluids, which suggests that the differences in alterations are due to differences in the precursor rocks, rather than differences in fluid composition. As described above (Fig. 6), the magnetic susceptibility values of hematite altered rock and their precursor rocks lie within the range $\sim 1.0$ to $\sim 50$ and 10 to $>100$, respectively. By comparison, the albite altered rocks and their precursors have values $<1$. Combining with the microscope observations that magnetite has been altered to hematite, the hematite in the alteration zones resulted from the oxidation of magnetite. Magnetite has been found in regional metamorphic veins, which suggests that it was probably an original mineral in the precursor rocks, or formed during regional metamorphism before gold mineralization. The sample shown in Figure 5b has both hematite and albite alterations surrounding the same vein. The hematite and albite alterations most likely occurred at the same time and, in both cases, alteration was produced by the same highly oxidized auriferous fluid. The difference between the hematite and albite alteration arises from variations in the magnetite content of the precursor rocks.

\section{Comparison with other deposits in the St. Ives camp}

The major gold deposits in the St. Ives camp include Victory-Defiance, Revenge, Argo, Intrepid, Athena-Hamlet, and Junction. Numerous detailed studies have been conducted on these deposits (Clark et al. 1986, 1989, Neumayr et al. 2008, Nguyen 1997), and a comparative study between these deposits with regards to host rocks, structure, and alteration was carried out by Watchorn (1998), but it does not include the more recently discovered Athena and Bellerophon deposits. Bellerophon is unique in terms of its wall rock alteration and ore mineral association.

A wide range of rocks types can host gold deposits at St. Ives, but most of the economic mineralization occurs in mafic-ultramafic rocks. Felsic intrusions are the second most common lithologies to host mineralization, 
e.g., Intrepid, Bellerophon, Flame porphyry from Victory, Bellesile, Beta porphyry. Furthermore, a significant fraction of the Bellerophon mineralization is hosted by the meta-sedimentary and felsic volcaniclastic rocks of the Black Flag Group, which was the first such discovery in St. Ives camp. Subsequently, other prospects have been found within the Black Flag Group and Merougil Creek Beds sedimentary sequences.

Two zones of wall rock alteration can be recognized in the St. Ives camp: an outer zone of chlorite alteration with biotite contents gradually increasing towards the center of the mineralized lodes, and an inner bleached alteration zone adjacent to the quartz veins, with quartz, albite, carbonate, and pyrite forming the lode itself (e.g., Clark et al. 1989, 1986, Watchorn 1998, Neumayr et al. 2008). In contrast, Bellerophon is characterized by strong albite-hematite and muscovite alteration zones, with a distinct absence of biotite alteration. Sulfide minerals at Bellerophon consist mainly of pyrite with trace amounts of chalcopyrite + galena, which is the same as for the other deposits in the St. Ives camp, except that some deposits contain pyrrhotite and arsenopyrite (Neumayr et al. 2008). Two types of magnetite occurred at Bellerophon: (1) the pre-gold mineralization magnetite, which can be oxidized into hematite during the hydrothermal alteration; and (2) hydrothermal magnetite, which was precipitated at the later stage of the gold mineralization and is intergrown with chlorite-quartz in the Stage IV veins. In comparison with other gold deposits in this region, hydrothermal magnetite minerals mostly predate or are coeval with the early stage of gold mineralization. In addition, sedimentary magnetite has been found in the sedimentary layers, e.g., the Kapai Slate. The mineralization styles of the Bellerophon deposits are similar to the other St. Ives deposits, and consist of quartz veins, quartz vein stock-work, breccias, and shear zones.

Neumayr et al. (2008) has documented that both reduced and oxidized assemblages occur in the St. Ives camp. Pyrrhotite-pyrite occurrences have been discovered in the Argo and Junction deposits, and hematite-pyrite minerals have been found in the Revenge deposit. Magnetite in the Kapai Slate has been observed to be oxidized into hematite during the hydrothermal alteration in the Victory gold deposit (Xu 1999). The wide range of $\delta^{34} \mathrm{~S}$ values for pyrite in the St. Ives camp also indicates variable redox conditions during mineralization. Accordingly, the mixing of two fluids with contrasting redox state has been proposed as the model for gold precipitation in the St. Ives camp (Neumayr et al. 2008). As stated above, all the mineral assemblages, e.g., the sulfate minerals and hematite, in Bellerophon represent oxidized conditions. The oxidation of magnetite into hematite during mineralization has been observed as well. Therefore, the fluid mixing theory cannot be applied to explain the mineralization in Bellerophon.
The most distinctive feature of the Bellerophon prospect is the abundance of telluride minerals, which account for about $15 \%$ of the Au. Telluride minerals have been reported at the Victory deposit by Clark et al. (1989), but in trace amounts. Blewett et al. (2008) and Clout (1989) argued that the gold mineralization that was coeval with D5 dextral deformation can contain significant amounts of base metals and tellurides. The low calcium granites in EGST crystallized within the same time period as the D5 deformation (2655 $2630 \mathrm{Ma}$, Blewett et al. 2008), which is similar to the age of formation of the gold deposits at the St. Ives camp (e.g., Miller et al. 2008, Nguyen 1997, Clark et al. 1986). By analogy, it is inferred that the Bellerophon deposit may have formed during the D5 deformation at about $2630 \mathrm{Ma}$. The monzonite and syenite intrusions at Bellerophon occurred as dikes, which can be cross cut by mineralized veins. Native gold and telluride minerals have been observed in these veins, and the Au grade can be over $20 \mathrm{~g} / \mathrm{t}$. Disseminated telluride minerals have also been found in the adjacent alteration halos of monzonite.

The $\mathrm{fS}_{2}$, fTe $\mathrm{Te}_{2}$ conditions for $\mathrm{Au}$ and telluride minerals deposition

The telluride and sulfosalt mineral assemblages can be used to estimate the $\mathrm{fS}_{2}$ and $f \mathrm{Te}_{2}$ of the auriferous hydrothermal fluid (e.g., Afifi et al. 1988a, b, Cabri 1965, Zhang \& Spry 1994). Different mineral assemblages correspond to distinct $f S_{2}, f \mathrm{Te}_{2}$ values for the fluid at a given temperature. Based on where the sulfide-sulfate assemblages at Bellerophon plot on an $\mathrm{fO}_{2}-\mathrm{T}$ diagram (Ohmoto \& Goldhaber 1997), the temperature of formation of these phases can be constrained to be around $300{ }^{\circ} \mathrm{C}$. Two sphalerite grains with $\mathrm{Fe}$ contents of $1.2-1.3 \%$, coexisting with pyrite in quartz-albite-carbonate-pyrite veins, requires a crystallization temperature of about $300{ }^{\circ} \mathrm{C}$ calculated from the pyrite-sphalerite geothermometer. Based on the above discussion we conclude that the temperature of the hydrothermal system was $\sim 300{ }^{\circ} \mathrm{C}$.

Gold and telluride minerals in the quartz-pyritecarbonate-albite veins can be further divided into three stages: the earliest involves minerals which are enclosed by pyrite or disseminated in the veins, e.g., bismuthtelluride, gold, calaverite, melonite, buckhornite, galena, and aikinite; stage two consists of minerals that fill the fractures in pyrite and include gold, altaite, and bismuthtelluride; the final stage is the assemblage of native tellurium and $\mathrm{Pb}-\mathrm{Cl}$ minerals that replaced altaite in the pyrite fractures. Intergrowth of gold and calaverite in the first stage can be used to constrain the upper boundary of $f \mathrm{Te}_{2}$. The coexistence of bismuthtelluride, tetradymite, and buckhornite suggests that the $f \mathrm{Te}_{2}$ and $f \mathrm{~S}_{2}$ values should lie close to the boundary between $\mathrm{Bi}_{2} \mathrm{~S}_{3}$ and $\mathrm{Bi}_{2} \mathrm{Te}_{3}$, which is consistent with the intergrowth between galena and aikinite in 


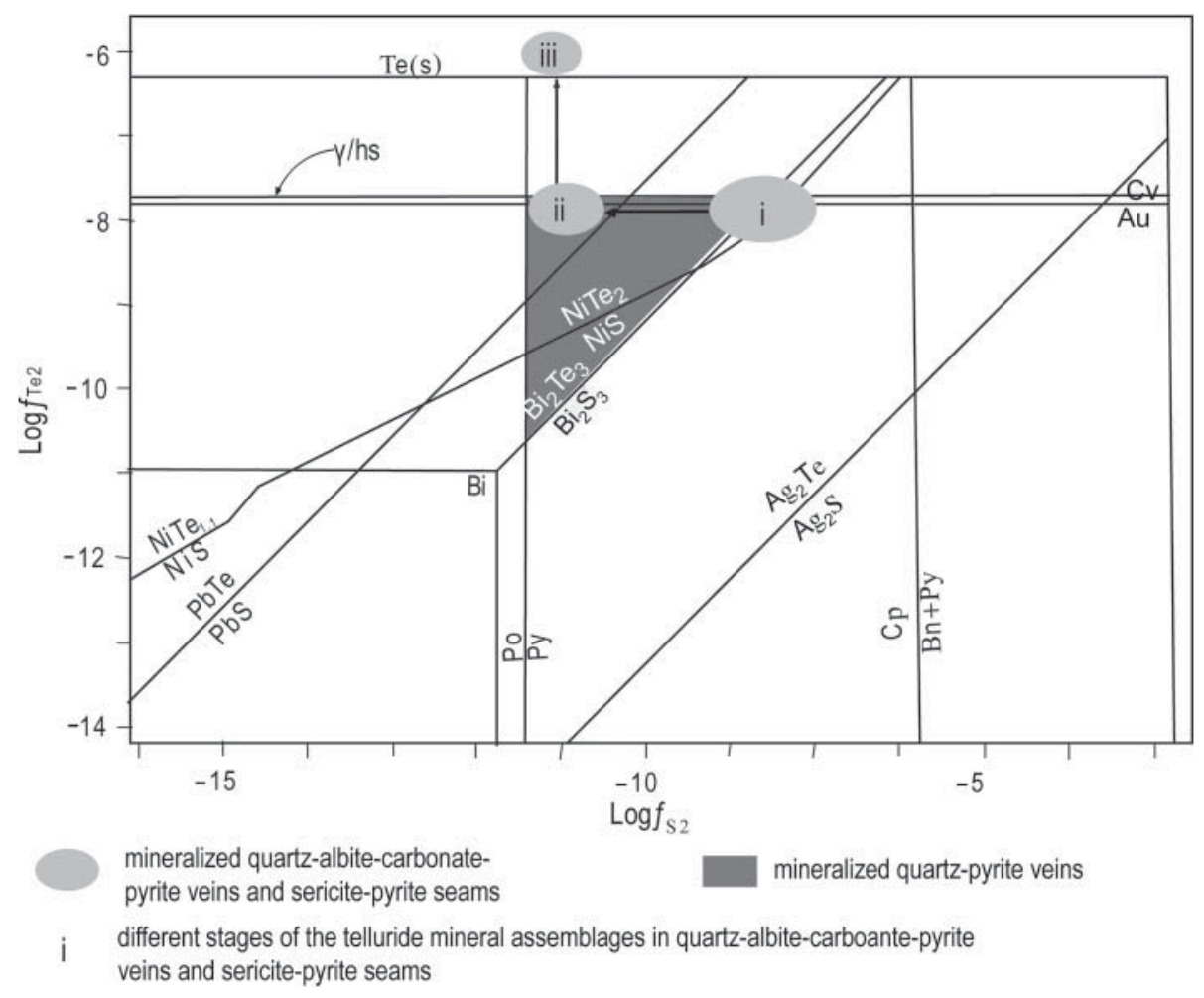

FIG. 9. Stability fields for selected telluride and sulfide phases on a plot of $f_{\mathrm{S} 2}$ against $f_{\mathrm{Te} 2}$ at $300{ }^{\circ} \mathrm{C}$ (Afifi et al. 1988a).

some samples. As seen from the $f S_{2}$ versus $f \mathrm{Te}_{2}$ diagram (Fig. 9), the first stage corresponds to a $\log \mathrm{Te}_{2}$ of -8 , and a $\log f \mathrm{~S}_{2}$ of -8 to -9 . The second stage mineral pairs of gold-altaite and altaite-bismuthtelluride give a $\log f \mathrm{Te}_{2}$ that is the same as the first stage, but $\log \mathrm{S}_{2}$ drops to -11 . After the second stage, chlorine-bearing fluids have replaced altaite and led to the crystallization of mixtures of native $\mathrm{Te} / \mathrm{Te}$-oxide and $\mathrm{Pb}-\mathrm{Cl}$ minerals, which require a $\log f \mathrm{Te}_{2}$ of up to -7.5 .

Native gold, telluride, and sulfosalt minerals are also found in the sheared sericite-pyrite seams, which can be again classified into the three stages recognized in the quartz-albite-carbonate-pyrite veins. The first stage involves native gold, galena, bismuthtelluride, buckhornite, and tetradymite, which are enclosed by pyrite. Altaite, gold, petzite, melonite, and rucklidgeite form the second stage, which fills in the pyrite fractures. In the third stage, chlorine-bearing minerals and native tellurium replaced bismuthtelluride. The association of bismuthtelluride and tetradymite constrains the crystallization conditions to lie close to the boundary between $\mathrm{Bi}_{2} \mathrm{~S}_{3}$ and $\mathrm{Bi}_{2} \mathrm{Te}_{3}$. Co-existing native gold and buckhornite constrain the upper limit of $f \mathrm{Te}_{2}$. The assemblage of altaite, gold, and petzite defines the stability of the second stage. The variations in the $\log f \mathrm{Te}_{2}$ and $\log f \mathrm{~S}_{2}$ of telluride minerals in the sheared sericite-pyrite veins are the same as those of the quartz-ankerite-pyrite-albite veins (Fig. 9), which suggests that the precipitation of native gold and telluride minerals in both systems was synchronous. Only native gold, calaverite, petzite, and bismuthtelluride were found in the quartz-pyrite veins. No temporal difference has been detected between these minerals. The values of $\log f \mathrm{Te}_{2}$ and $\log f \mathrm{~S}_{2}$ of the quartz-pyrite veins are constrained to lie between -8 and -11 , and -9 and -11.5 , respectively.

Telluride minerals can also be used to determine the redox state of the hydrothermal fluid. The Bellerophon tellurides, with $\mathrm{Bi} /(\mathrm{Te}+\mathrm{S})<1$, e.g., the tellurobismuthite $\left(\mathrm{Bi}_{2} \mathrm{Te}_{3}\right)$ and tetradymite $\left(\mathrm{Bi}_{2} \mathrm{Te}_{2.1} \mathrm{~S}_{1}\right)$, require oxidized conditions (Afifi et al. 1988a, b). Furthermore, $\mathrm{Au}-\mathrm{Ag})$-telluride and native tellurium or Te-oxide minerals also crystallize under oxidized conditions (Zhang \& Spry 1994). McPhail (1995) suggests that the stability of native Te broadly covers the pyrite field in $f \mathrm{~S}_{2}-f \mathrm{O}_{2}$ space with a solubility minimum close to the Mt-Hem buffer at $300^{\circ} \mathrm{C}$

In summary, both the quartz-albite-carbonate-pyrite veins and sericite-pyrite seams require $\log f \mathrm{~S}_{2}$ values to decrease from -8 to -11 , with $\log f \mathrm{Te}_{2}$ remaining at 


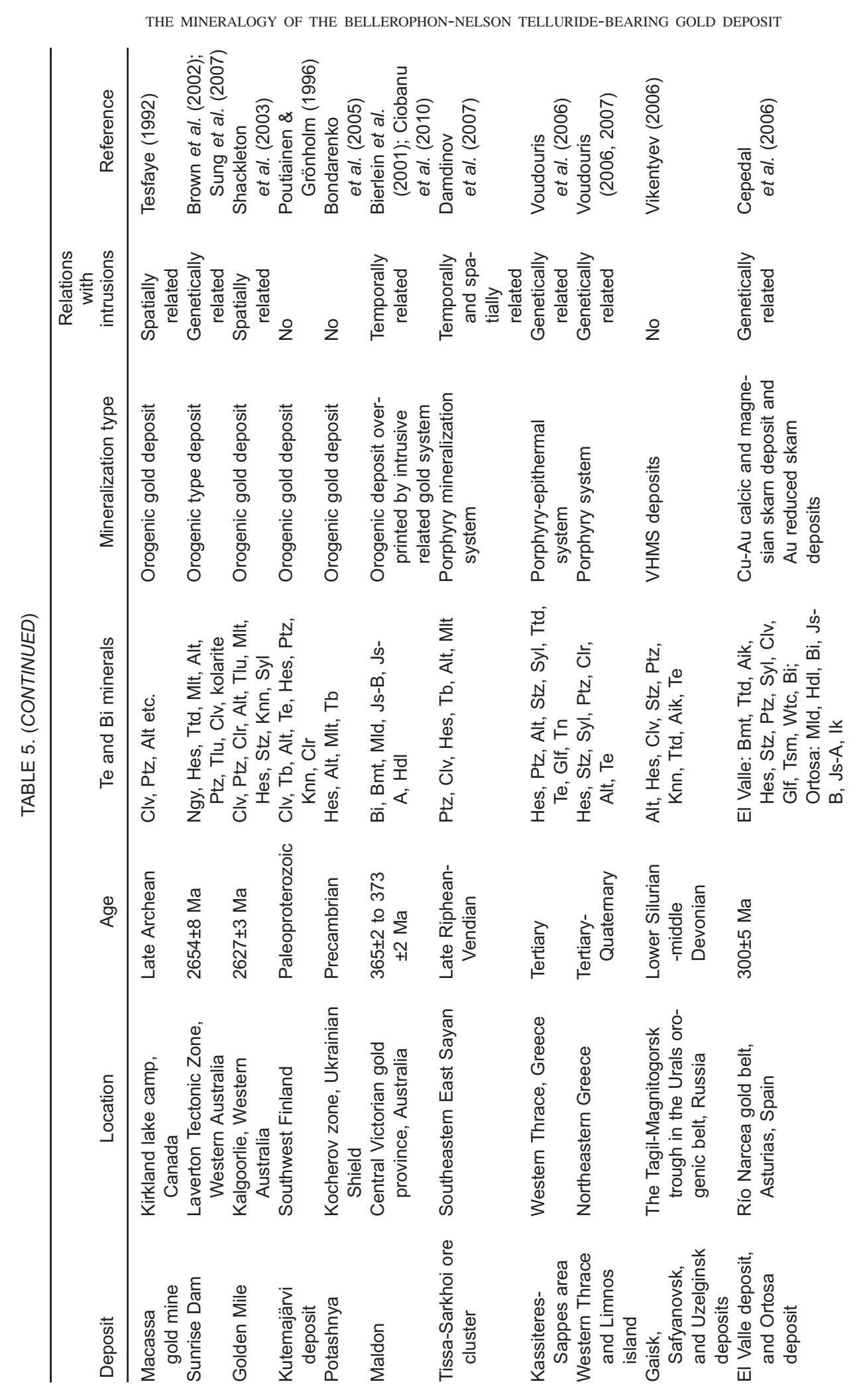


about -8 . The chlorine replacement reactions require $\log f \mathrm{Te}_{2}$ to increase to the stable field of native tellurium. $\log f \mathrm{Te}_{2}$ and $\log f \mathrm{~S}_{2}$ in the quartz-pyrite veins should lie within the ranges -8 to -11 and -9 to -11.5 , respectively. The decrease in $\log f \mathrm{Te}_{2}$ values from the end of quartz-albite-carbonate-pyrite vein formation to the start of formation of the quartz-pyrite veins corresponds to the appearance of native Te. The associated decrease in $\mathrm{fS}_{2}$ corresponds to pyrite crystallization, which may have caused gold precipitation. The telluride mineral assemblage indicates a highly oxidized environment, which is consistent with hematite alteration and sulfate minerals detected in the veins.

\section{Comparison with other gold telluride deposits}

Tellurides and sulfosalt minerals are present as trace constituents in many gold deposits from different parts of the world. However, deposits in which telluride minerals are major $\mathrm{Au}$ reservoirs are rare. Examples include the Sandaowanzi gold deposit in China, Sacarimb in Romania, and the Golden Mile in Western Australia, with $100 \%, 50 \%$, and $>20 \%$ of the Au held in telluride minerals, respectively (Liu et al. 2011, Cook et al. 2005, Shackleton et al. 2003). Telluride minerals have been reported in the Yilgarn craton from the Golden Mile, Sunrise Dam, Victory, Jupiter, Chalice, Kanowna Belle, and Porphyry gold deposits (Clout 1989, Shackleton et al. 2003, Sung et al. 2007, Clark et al. 1989, Cleverley \& Nugus 2008). However, only the first two of these and the Bellerophon prospect can be termed Au-tellurides deposits because of the abundant contents of telluride minerals. Representative $\mathrm{Au}-\mathrm{Te}$ deposits are summarized in Table 5. These deposits cover a wide range in ages from late Archaean to Neocene.

$\mathrm{Au}-\mathrm{Te}$ mineralization has been reported from a variety of types of gold deposits, with low sulfidation epithermal being the most important (Table 5, e.g., Cripple Creek, Colorado; Emperor, Fiji; El Indo, Chile). Low sulfidation epithermal gold mineralization is interpreted to be related to alkaline-calc to alkaline arc magmatism (e.g., Kelley \& Ludington 2002, Cooke \& McPhail 2001, Cook et al. 2009). Gold-telluride deposits from porphyry, skarn, intrusion related, and VMS types of mineralization are also interpreted to be genetically related to magmatism. All these examples suggest that the Te-enriched auriferous fluid is derived from a magmatic system. A positive correlation between $\mathrm{Au}$ and $\mathrm{Te}, \mathrm{Bi}, \mathrm{W}$, As, and $\mathrm{Pb}$ has also been identified at the Bellerophon prospect, which is consistent with the magmatic source hypothesis (Baker et al. 2005, Meinert 2000, Tooth et al. 2008), as is the spatial relation between gold mineralization and alkaline intrusions in Bellerophon. However, further studies, including 
geochronology and radiogenic isotope analyses, are necessary to support this point for Bellerophon.

Another notable feature of Bellerophon mineralogy is the presence of Cl-bearing minerals. These minerals have only previously been reported from the Kolar gold deposit in India and the Sunrise Dam gold-telluride deposit in Western Australia (Table 5, Genkin et al. 1985, Sung et al. 2007, Sung 2008), where kolarite $\left(\mathrm{PbTeCl}_{2}\right)$ and radhakrishnaite $\left[\mathrm{PbTe}_{3}(\mathrm{Cl}, \mathrm{S})_{2}\right]$ have been found. However, the Cl-bearing minerals in the Bellerophon deposit are $\mathrm{PbCl}(\mathrm{OH})$ mixed with $\mathrm{Pb}_{2} \mathrm{Cl}_{3}(\mathrm{OH})$ and $\mathrm{BiOCl}$ mixed with $\mathrm{BiO}(\mathrm{OH}, \mathrm{Cl})$, which have not previously been reported from gold deposits. The gold grains in association with Cl-bearing minerals in the Bellerophon deposit are interpreted to have precipitated from a later and lower-temperature hydrothermal event.

\section{CONCLUSION}

Gold at the Bellerophon gold prospect is hosted mainly by the meta-sedimentary rocks of the Black Flag Group, but the spatially associated monzonite and albitite dikes also carry significant mineralization. Four stages of mineralization have been identified: Stage I, quartz-carbonate veins; Stage II, quartzalbite-carbonate-pyrite veins and sericite-pyrite seams; Stage III, quartz-pyrite veins; and Stage IV, carbonate-chlorite/carbonate veins. Gold-bearing minerals, including native gold and Au-tellurides, crystallized during Stages II and III. Extension veins and breccia textures and sericite-pyrite seams provide evidence for brittle and ductile deformation, respectively, and both are synchronous with gold mineralization. Intense hematite and albite alterations, which envelop the mineralized veins, are interpreted to be coeval and derived from the same hydrothermal fluid that deposited the ore minerals. Thirteen telluride and sulfosalt minerals have been identified from Bellerophon deposit, and these carry about $15 \%$ of the Au. The most common telluride minerals include calaverite, petzite, altaite, and tellurobismuthite. The mineral associations of $\mathrm{PbCl}(\mathrm{OH})-\mathrm{Pb}_{2} \mathrm{Cl}_{3}(\mathrm{OH})-\mathrm{Te}-\mathrm{TeO}_{2}$ and $\mathrm{BiOCl}-\mathrm{BiO}(\mathrm{OH}, \mathrm{Cl})-\mathrm{Te}-\mathrm{TeO}_{2}$ from Stage II were formed by replacement of telluride minerals during reactions with a Cl-bearing fluid. The hematite alteration, sulfate minerals in the veins, and the telluride minerals assemblage at Bellerophon all indicate a highly oxidized auriferous fluid. The telluride and sulfosalt mineralogy suggest the $\log f \mathrm{~S}_{2}$ value during Stage II decreased from about -8 to -11 , while $\log f \mathrm{Te}_{2}$ was initially about -8 , before rising into the stability field of native tellurium. During Stage III, the $\log f \mathrm{Te}_{2}$ and $\log f \mathrm{~S}_{2}$ were about -8 to -11 and -9 to -11.5 , respectively. The highly oxidized nature of the tellurium-enriched auriferous fluid is consistent with the involvement of magmatic fluid during mineralization.

\section{ACKNOWLEDGEMENTS}

The authors acknowledge Gold Fields St. Ives Mining Company for financial support, access to records and core and logistical support. We are especially grateful to Ayesha Ahmed, Julian Woodcock, and Malcolm Jolly from St. Ives for the arrangement of field trips. Gustav Nortje (Newmont Mining Company) and Damien Keys (Silver Lake Resources) previously of Gold Fields Ltd.-St. Ives were important in getting the project off the ground. The Centre for Advanced Microscopy at the Australian National University is thanked for providing SEM time. Charlotte Allen, Frank Brink, and Hua Chen from the Australian National University are all thanked for their technical support for SEM analysis. Special thanks are given to Dr. Tyson Birkett, Dr. Andreas Mueller, and the anonymous reviewers for their suggestions to improve the manuscript.

\section{REFERENCES}

Afifr, A.M., Kelly, W.C., \& Essene, E.J. (1988a) Phase relations among tellurides, sulfides, and oxides: I. Thermochemical Data and Calculated Equilibria. Economic Geology 83, 377-394.

Afifi, A.M., Kelly, W.C., \& Essene, E.J. (1988b) Phase relations among tellurides, sulfides, and oxides: II. Applications to telluride-bearing ore deposits. Economic Geology 83, 395-404.

Baker, T., Pollard, P.J., Mustard, R., Mark, G., \& Graham, J.L. (2005) A comparison of granite-related tin, tungsten, and gold-bismuth deposits: Implications for exploration. Society of Economic Geologists Newsletter 61, 5-17.

Bateman, R., Costa, S., Swe, T., \& Lambert, D. (2001) Archaean mafic magmatism in the Kalgoorlie area of the Yilgarn Craton, Western Australia: a geochemical and $\mathrm{Nd}$ isotopic study of the petrogenetic and tectonic evolution of a greenstone belt. Precambrian Research 108, $75-112$.

Bierlein, F.P., Arne, D.C., Foster, D.A., \& Reynolds, P. (2001) A geochronological framework for orogenic gold mineralization in central Victoria, Australia. Mineralium Deposita 36, 741-767.

Blewett, R. S. Czarnota, K. \& Henson, P.A. (2008) A revised structural-event framework for the Eastern Goldfields Superterrane. In Pmd* CRC Project Y4 final report: Concepts to Targets: a scale integrated mineral systems study of the Eastern Yilgarn Craton (R.S. Blewett, ed.). Geoscience Australia, Canberra, Australia (53-82). 
Blewett, R.S., Seuire, R., Miller, J.M., Henson, P.A., \& Champion, D.C. (2010) Architecture and geodynamic evolution of the St. Ives region south central Kalgoorlie Terrane, Western Australia. Precambrian Research 183, 275-291.

Bondarenko, S., Grinchenko, O., \& Semka, V. (2005) AuAg-Te-Se mineralization in the Potashnya gold deposit, Kocherov tectonic zone, Ukrainian Shield. Geochemistry. Mineralogy and Petrology 43, 20-27.

Brown, S.M., Fletcher, I.R., \& Stein, H.J. (2002) Geochronological constrains on pre-syn and post mineralization events at the world class Cleo gold deposit, Eastern Goldfields province, Western Australia. Economic Geology 97, 541-559.

CABri, L.J. (1965) Phase relations in the Au-Ag-Te system and their mineralogical significance. Economic Geology 60, 1569-1606.

Cassidy, K.F. \& Hagemann, S.G. (2001) 'World-class' Archaean orogenic gold deposits, eastern Yilgarn Craton: diversity in timing, structural controls and mineralization styles. AGSO-Geoscience Australia Record 2001/37, 382-384.

Cassidy, K.F., Champion, D.C., Krapez, B., Barley, M.E., Brown, S.J.A., Blewett, R.S., Groenewald, P.B., \& Tyler, I.M. (2006) A revised geochronological framework for the Yilgarn Craton, Western Australia. Western Australia Geological Survey Record 2006/8, 8.

Cepedal, A., Fuertes-Fuente, M., Martin-Izard, A., GonZalez-Nistal， S., \& RodrigueZ-Pevida, L. (2006) Tellurides, selenides and $\mathrm{Bi}$ mineral assemblages from the Rio Narcea gold belt, Asturias, Spain: genetic implications in $\mathrm{Cu}-\mathrm{Au}$ and $\mathrm{Au}$ skarns. Mineralogy and Petrology 87, 277-304.

Champion, D.C. \& Sheraton, J.W. (1997) Geochemistry and $\mathrm{Nd}$ isotope systematics of Archaean granites of the Eastern Goldfields, Yilgarn Craton, Australia: Implications for crustal growth processes. Precambrian Research 83, 109-132.

Ciobanu, C.L., Birch, W.A., Cook, N.J., Pring, A., \& Grundler, P.V. (2010) Petrogenetic significance of AuBi-Te-S associations: the example of Maldon central Victorian gold province, Australia. Lithos 116, 1-17.

Clark, M.E., Archibald, N.J., \& Hodgson, C.J. (1986) The structural and metamorphic setting of the Victory gold mine, Kambalda, Western Australia. In International Symposium on the Gold Deposits, Gold'86 (A.J. Macdonald, ed.). Konsult International Inc., Toronto, Ontario, Canada (243-254).

Clark, M.E., Carmichael, D.M., Hodgson, C.J., \& Fu, M. (1989) Wall-rock alteration, Victory gold mine, Kambalda, Western Australia: Processes and P-T-X (CO2) conditions of metasomatism. Economic Geology Monograph 6, 445-459.
Cleverley, J. \& Nugus, M. (2008) Fluid-chemical evolution of the Sunrise Dam mineral system. In Pmd* CRC Project Y4 final report: Concepts to Targets: a scale intergrated mineral systems study of the Eastern Yilgarn Craton (R.S. Blewett, ed.). Geoscience Australia, Canberra, Australia (350-376).

Clout, J.M.F. (1989) Structural and isotopic studies of the Golden Mile gold-telluride deposit, Kalgoorlie, Western Australia. Monash University, Ph.D. thesis, Melbourne, Australia.

Compston, W., Williams, I.S., Campbell, I.H., \& Gresham, J.J. (1986) Zircon xenocrysts from the Kambalda volcanics: age constraints and direct evidence for older continental crust below the Kambalda-Norseman greenstones. Earth and Planetary Science Letters 76, 299-311.

Cook, N.J., Ciobanu, C.L., Capraru, N., Damian, G., \& Cristea, P. (2005) Mineral assemblages from the vein salband at Sacarimb, Golden Quadrilateral, Romania: II tellurides. Geochemistry, Mineralogy and Petrology 43, 56-63.

Cook, N.J., Ciobanu, C.L., \& Mao, J.W. (2009) Textural control on gold distribution in As-free pyrite from the Dongping, Huangtuliang and Hougou gold deposits, North China Craton (Hebei Province, China). Chemical Geology 264, 101-121.

Cook, N.J., Ciobanu, C.L., \& Spry, P.G. (2009) Understanding gold-(silver)-telluride-(selenide) mineral deposits. Episodes 32, 249-263.

Cooke, D.R. \& McPhail, D.C. (2001) Epithermal Au-Ag-Te mineralization Acupan, Baguio district, Philippines numerical simulations of mineral deposition. Economic Geology 96, 109-131.

Cooke, D.R., McPhall, D.C., \& Bloom, M.S. (1996) Epithermal gold mineralization, Acupan Baguio district, Philippines: Geology mineralization alteration and the thermochemical environment of the ore deposition. Economic Geology 91, 243-272.

Czarnota, K., Champion, D.C., Goscombe, B., Blewett, R.S., Henson, P.A., Cassidy, K.F., \& Groenewald, B. (2008) Question 1: Geodynamics of the Eastern Goldfields Superterrane. In Pmd* CRC Project Y4 final report: Concepts to Targets: a scale intergrated mineral systems study of the Eastern Yilgarn Craton, (R.S. Blewett, ed.). Geoscience Australia, Canberra, Australia (10-52).

Damdinov, B.B., Mironov, A.G., Borovikov, A.A., Guntypov, B.B., Karmanov, N.S., Borisenko, A.S., \& Garmaev, B.L. (2007) Composition and conditions of formation of gold telluride mineralization in the Tissa Sarkhoi gold bearing province (East Sayan). Russian Geology and Geophysics 48, 643-655.

Duuring, P., Hagemann, S.G., \& Groves, D.I. (2000) Structural setting, hydrothermal alteration, and gold mineralization at the Archean syenite hosted Jupiter deposit Yilgarn Craton. Mineralium Deposita 35, 402-421. 
Duuring, P., Hagemann, S.G., Cassidy, K.F., \& Johnson, C.A. (2004) Hydrothermal alteration, ore fluid characteristics and gold depositional processes along a trondhjemite-komatiite contact at Tarmoola, Western Australia. Economic Geology 99, 423-451.

Fadda, S., Fiori, M., Grillo, S.M., \& Matzuzzi, C. (2005) Polymetallic assemblages with precious metal tellurides and sulfosalts from the Furtei epithermal $\mathrm{Au}$ deposit, Sardinia Italy: paragenesis and genetic significance. In Mineral Deposit Research: Meeting the Global Challenge (J. Mao \& F.P. Bierlein, eds.). Springer, Berlin, Germany (1395-1398).

Genkin, A.D., Safonov, Y.G., Vasudev, V.N., Krishna-Rao, B., Boronikhin, V.A., Vyalsov, L.N., Gorshkov, A.I., \& Mокноv, A.V. (1985) Kolarite $\mathrm{PbTeCl}_{2}$ and Radhakerishnaite $\mathrm{PbTe}_{3}(\mathrm{Cl}, \mathrm{S})_{2}$, new mineral species from the Kolar gold deposit, India. Canadian Mineralogist 23, 501-506.

Goldfarb, R.J., Groves, D.I., \& Gardoll, S. (2001) Orogenic gold and geologic time: A global synthesis. Ore Geology Reviews 18, 1-75.

Goscombe, B., Blewett, R.S., Czarnota, K., Maas, R., \& Groenewald, B.A. (2007) Broad thermo-barometric evolution of the Eastern Goldfields Superterrane. In Proceedings of of the Kalgoorlie '07 Conference (F.P. Bierlein \& C.M. Knox-Robinson, eds.). Geoscience Australia Record 2007/14, 33-38.

Groves, D.I., Goldfarb, R.J., Gebre-Mariam, M., Hagemann, S.G., \& Robert, F. (1998) Orogenic gold deposits: A proposed classification in the context of their crustal distribution and relationship to other gold deposit types. Ore Geology Reviews 13, 7-27.

HeAth, C.J. (2003) Fluid flow at the giant Golden Mile deposit, Kalgoorlie, Western Australia. Unpublished Ph.D. thesis, Australian National University, Canberra, Australia (173 pp.).

Ho, S.E., Groves, D.I., McNaughton, N.J., \& Mikucki, E.J. (1992) The source of ore fluid and solutes in Archean lode gold deposits of Western Australia. Journal of Volcanology and Geothermal Research 50, 173-196.

Jannas, R.R., Beane, R.E., Ahler, B.A., \& Brosnahan, D.R. (1990) Gold and copper mineralization at the El Indio deposit, Chile. Journal of Geochemical Exploration 36, 233-266.

Kelley, K.D. \& Ludington, S. (2002) Cripple Creek and other alkaline-related gold deposits in the southern Rocky Mountains, USA: influence of regional tectonics. Mineralium Deposita 37, 38-60.

Kelley, K.D., Romberger, S.B., Beaty, D.W., Pontius, J.A., Snee, L.W., Stein, H.J., \& Thompson, T.B. (1998) Geochemical and geochronological constraints on the genesis of Au-Te deposits at Cripple Creek, Colorado. Economic Geology 93, 981-1012.
Kovalenker, V.A., Plotinskaya, O.Y., \& Koneev, R.I. (2003) Mineralogy of epithermal gold sulfide telluride ores of the Kairagach gold deposit Uzbekistan. New Data on Minerals 38, 45-56.

Krapež, B., Brown, B.J.A., Hand, J., Barley, M.E., \& Cas, R.J.F. (2000) Age constraints on recycled crustal and supracrustal sources of Archaean metasedimentary seqeuences, Eastern Goldfields Province, Western Australia: Evidence from SHRIMP zircon dating. Tectonophysics 322, 89-133.

LiU, J.L., Bai, X.D., Zhao, S.J., Tran, M.D., Zhang, Z.C., Zhao, Z.D., Zhao, H., \& Lu, J. (2011) Geology of the Sandaowanzi telluride gold deposit of the northern Great Xing'an Range, NE China: Geochronology and tectonic controls. Journal of Asian Earth Sciences 41, 107-118.

McNaughton, N.J., Mueller, A.G., \& Groves, D.I. (2005) The age of the giant Golden Mile deposit, Kalgoorlie, Western Australia: Ion-Microprobe zircon and Monazite $\mathrm{U}-\mathrm{Pb}$ geochronology of a synmineralization lamprophyre dyke. Economic Geology 100, 1427-1440.

McPhall, D.C. (1995) Thermodynamic properties of aqueous tellurium species between $25{ }^{\circ} \mathrm{C}$ and $350{ }^{\circ} \mathrm{C}$. Geochimica et Cosmochimica Acta 59, 851-866.

MeinerT, L.D. (2000) Gold in skarns related to epizonal intrusions. Reviews in Economic Geology 13, 347-375.

Miller, J.M., Tunjic, J., Donaldson, J., \& Blewett, R.S. (2008) Structural evolution of the Victory to Kambalda region of the St. Ives gold camp: the role of early formed structures on the development of a major gold system. In Pmd* CRC Project Y4 final report: Concepts to Targets: a scale integrated mineral systems study of the Eastern Yilgarn Craton (R.S. Blewett, ed.). Geoscience Australia, Canberra, Australia (218-253)

Mueller, A.G., Hall, G.C., Nemchin, A.A., Stein, H.J., Creaser, R.A., \& Mason, D.R. (2008) Archaean high Mg monzodirotie syentie epidote skarn, and biotite sericite gold lodes in the Granny Smith-Wallaby district, Australia: U-Pb and Re-Os chronometry of two intrusion related hydrothermal systems. Mineralium Deposita 433, 337-362.

Nelson, D.R. (1997) Evolution of the Archaean granitegreenstone terranes of the Eastern Goldfields, Western Australia: SHRIMP U-Pb zircon constraints. Precambrian Research 83, 57-81.

Neumayr, P., Walshe, J., Hagemann, S., Petersen, K., Roache, A., Frikken, P., Horn, L., \& Halley, S. (2008) Oxidized and reduced mineral assemblages in greenstone belt rocks of the St. Ives gold camp, Western Australia: vectors to high grade ore bodies in Archean gold deposits? Mineralium Deposita 43, 363-371.

NGUYEn, P.T. (1997) Structural controls on gold mineralization at the Revenge mine and its tectonic setting in the Lake Lefroy area, Kambalda, Western Australia. Ph.D. thesis, The University of Western Australia, Perth, Australia. 
Oberthür, T. \& Weiser, T.W. (2008) Gold-bismuth-telluridesulphide assemblages at the Viceroy mine, Hrare-BinduraShamva greenstone belt, Zimbabwe. Mineralogical Magazine 72, 953-970.

Онмото, H. \& Goldhaber, M.B. (1997) Sulfur and carbon isotopes. In Geochemistry of Hydrothermal Ore Deposits, 3rd Edition (H.L. Barnes, ed.). John Wiley \& Sons, New York, United States (517-612).

PAls, D.W. \& Spry, P.G. (2003) Telluride mineralogy of the low sulfidation epithermal Emperor gold deposit, Vatukoula, Fiji. Mineralogy and Petrology 79, 285-307.

Perring, C.S. \& McNaughton, N.J. (1992) The relationship between Archaean gold mineralization and spatially associated minor intrusions at the Kambalda and Norseman gold camps, Western Australia: Lead isotope evidence. Mineralium Deposita 27, 10-22.

Plotinskaya, O.Y., Kovalenker, V.A., Seltmann, R., \& STANLEY, C.J. (2006) Te and Se mineralogy of the high sulfidation Kochbulak and Kairagach epithermal gold telluride deposits (Kurama Ridge, middle Tienshan, Uzbekistan). Mineralogy and Petrology 87, 187-207.

Poutiainen, M. \& Grönholm, P. (1996) Hydrothermal fluid evolution of the paleoproterozoic Kutemajarvi gold telluride deposit, southwest Finland. Economic Geology 91, 1335-1353.

Qui, Y. \& McNaughton, N.J. (1999) Source of Pb in orogenic lode-gold mineralization; $\mathrm{Pb}$ isotope constraints from deep crustal rock from the southwestern Archaean Yilgarn Craton, Australia. Mineralium Deposita 34, 366-381.

RoBERT, F. (2001) Syenite associated disseminated gold deposits in the Abitibi greenstone belt, Canada. Mineralium Deposita 36, 503-516.

Robert, F., Paulsen, K.H., Cassidy, K.F., \& Hodgson, C.J. (2005) Gold metallogeny of the Superior and Yilgarn cratons. Economic Geology: One Hundredth Anniversary Volume, 1001-1033.

Rock, N.M., TAYlor, W.R., \& Perring, C.S. (1990) Gold deposits of the Archaean Yilgarn block, Western Australia: Nature, genesis and exploration guides. The University of Western Australia, Publication 20, 128-135.

Ross, A.A., Barley, M.E., Brown, S.J.A., McNaughton, N.J., Ridley, J.R., \& Fletcher, I.R. (2004) Young porphyries, old zircons: new constraints on the timing of deformation and gold mineralization in the eastern goldfields from SHRIMP U-Pb zircon dating at the Kanowna Belle Gold Mine, Western Australia. Precambrian Research 128, $105-142$.

Scherbarth, N.L. \& Spry, P.G. (2006) Mineralogical, petrological, stable isotope, and fluid inclusion characteristics of the Tuvatu gold silver telluride deposit, Fiji: comparisons with the Emperor deposit. Economic Geology 101, $135-158$.
Shackleton, J.M., Spry, P.G., \& Bateman, R. (2003) Telluride mineralogy of the Golden Mile deposit, Kalgoorlie Western Australia. Canadian Mineralogist 41, 1503-1524.

Siddeley, G. \& Araneda, R. (1986) EI Indio-Tambo gold deposits, Chile. In International Symposium on the Gold Deposits, Gold'86 (A.J. Macdonald, ed.), Konsult International Inc., Toronto, Canada (445-456).

Spry, P.G., Paredes, M.M., Foster, F., \& Truckle, J.S. (1996) Evidence for a genetic link between gold silver telluride and porphyry molybdenum mineralization at the Golden Sunlight Deposit, Whitehall Montana: fluid inclusion and stable isotope studies. Economic Geology 91, 507-526.

Spry, P.G., Foster, F., Truckle, J.S., \& Chadwick, T.H. (1997) The mineralogy of the Golden Sunlight gold silver telluride deposit Whitehall, Montana USA. Mineralogy and Petrology 59, 143-164.

Spry, P.G., Tombros, S.F., St. Seymour, K., WilliamsJones, A., \& Zouzias, D.P. (2006) Geology, mineralization, and geochemistry of granite hosted gold telluride mineralization at Panormos Bay Tinos island Greece. Geological Society of America Abstracts with Programs 38, 55.

Souire, R.J., Allen, C.M., Cas, R.A.F., Campbell, I.H., Blewett, R.S., \& Nemchin, A.A. (2010) Two cycles of voluminous pyroclastic volcanism and sedimentation related to episodic granite emplacement during the late Archean: Eastern Yilgarn Craton, Western Australia. Precambrian Research 183, 251-274.

STOLTzE, A.M. (2006) Is proximal carbonatite magmatism the source of gold at the Wallaby Deposit, Western Australia? $\mathrm{Ph} . \mathrm{D}$. thesis, The Australian National University, Canberra, Australia.

Sung, Y.H. (2008) The nature of gold mineralization in the multistage Archean Sunrise Dam gold deposit, Eastern Yilgarn craton, Western Australia. Ph.D. thesis, The University of South Australia, Adelaide, Australia.

Sung, Y.H., Ciobanu, C.L., Pring, A., Brugger, J., Skinner, W., Cook, N.J., \& Nugus, M. (2007) Tellurides from Sunrise Dam gold deposit, Yilgarn craton Western Australia: a new occurrence of nagyágite. Mineralogy and Petrology 91, 249-270.

Swager, C.P. (1997) Tectono-stratigraphy of late Archaean greenstone terranes in the southern Eastern Goldfields, Western Australia. Precambrian Research 83, 11-42.

Tesfaye, G. (1992) Ore microscopic and geochemical characteristics of gold tellurides sulfide minealization in the macassa gold mine, Abitibi belt, Canada. Mineralium Deposita 27, 66-71.

Tooth, B., Brugger, J., Ciobanu, C., \& Liu, W.H. (2008) Modeling of gold scavenging by bismuth melts 
coexisting with hydrothermal fluids. Geology 36, $815-818$.

Twemlow, S.G. (1984) Archaean gold telluride mineralization of the Commoner mine, Zimbabwe. In The Geology, Geochemistry and Genesis of gold deposits, Gold' 82 (R.P. Foster, ed.). A.A. Balkema Publications, Rotterdam, Netherlands (469-492).

Vikentyev, I.V. (2006) Precious metal and telluride mineralogy of large volcanic hosted massive sulfide deposits in the Urals. Mineralogy and Petrology 87, 305-326.

Voudouris, P. (2006) A comparative mineralogical study of Te rich magmatic hydrothermal systems in northeastern Greece. Mineralogy and Petrology 87, 241-275.

Voudouris, P. (2007) The mineralogy and genesis of precious metal telluride deposits of Greece. Geological Society of America Abstracts with Programs 39, 625.

Voudouris, P., TARKIAN, M., \& ARIKAS, K. (2006) Mineralogy of telluride bearing epithermal ores in the Kassiteres-Sappes area, western Thrace, Greece. Mineralogy and Petrology 87 , $31-52$.

Walshe, J.L., Neumayr, J., Cleverley, K., Petersen, K., Andrew, A., Whitford, D., CARr, G.R., Kendrick, M., Young, C., \& Halley, S. (2008) Question 3: Multiple fluid reservoirs in Eastern Yilgarn gold systems. In Pmd* CRC Project Y4 final report: Concepts to Targets: a scale intergrated mineral systems study of the Eastern Yilgarn Craton
(R.S. Blewett, ed.). Geoscience Australia, Canberra, Australia (113-153).

Watchorn, R.B. (1998) Kambalda-St Ives gold deposits. In Geology of Australian and Papua New Guinea Mineral Deposits (D.A. Berkman \& D.H. Mackenzie, eds.). The Australian Institute of Mining and Metallurgy, Melbourne, Australia (243-254).

WITT, W.K. (1992) Porphyry intrusions and albitites in the Bardoc Kalgoorlie area, Western Australia, and their role in Archean epigenetic gold mineralization. Canadian Journal of Earth Sciences 29, 1609-1622.

Xu, Y.H. (1999) The stable isotope and trace element geochemistry of the Victory gold deposit, Western Australia. Ph.D. thesis, The Australian National University, Canberra, Australia (163 pp.).

Xue, Y.X. (2014) The Genesis of the Bellerophon Gold deposit, St Ives Camp, Yilgarn Craton-An example of a magmatic-hydrothermal gold deposit. Ph.D. thesis, The Australian National University, Canberra, Australia (228 pp.).

Zhang, X.M. \& Spry, P.G. (1994) Calculated stability of aqueous tellurium species, calaverite and hessite at elevated temperatures. Economic Geology 89, 1152-1166.

Received January 24, 2014, revised manuscript accepted December 6, 2014. 
